
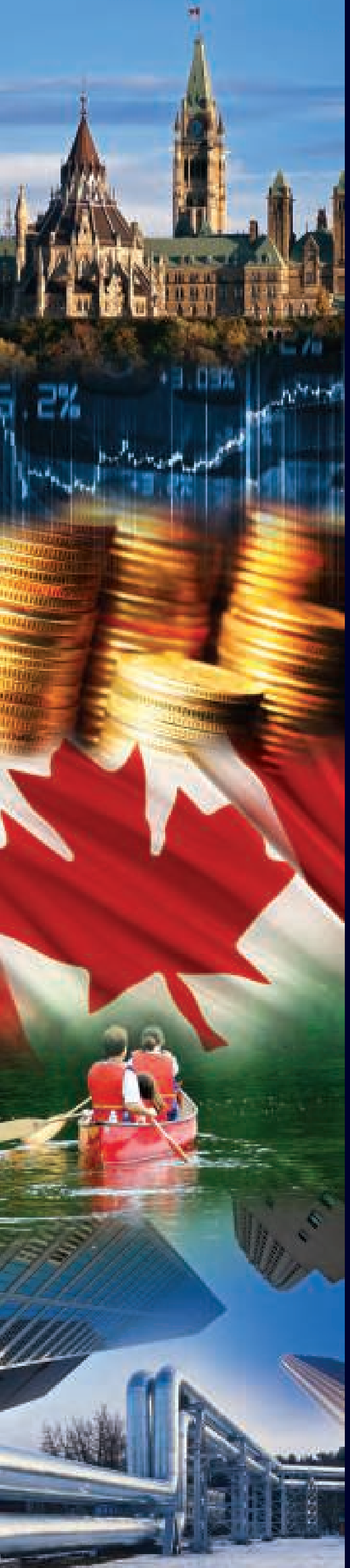

COMMENTARY

NO. 536

\title{
Entrepreneurial Finance and Economic Growth: A Canadian Overview
}

Equity capital is the fuel that helps firms scale up and boost Canada's productivity and economic growth. Tax relief could remove hurdles that discourage entrepreneurs from moving up to the next stage of growth.

\section{Pierre Lortie}




\section{THE C.D. HOWE INSTITUTE'S COMMITMENT TO QUALITY, INDEPENDENCE AND NONPARTISANSHIP}

ABOUT THE AUTHOR

Pierre Lortie is Senior Business Advisor, Dentons Canada LLP and a board member of ECN Capital.
Commentary No. 536

February 2019

Financial Services and

Regulation
$\$ 12.00$

ISBN 978-1-987983-94-4 ISSN 0824-8001 (print); ISSN 1703-0765 (online)
The C.D. Howe Institute's reputation for quality, integrity and nonpartisanship is its chief asset.

Its books, Commentaries and E-Briefs undergo a rigorous two-stage review by internal staff, and by outside academics and independent experts. The Institute publishes only studies that meet its standards for analytical soundness, factual accuracy and policy relevance. It subjects its review and publication process to an annual audit by external experts.

As a registered Canadian charity, the C.D. Howe Institute accepts donations to further its mission from individuals, private and public organizations, and charitable foundations. It accepts no donation that stipulates a predetermined result or otherwise inhibits the independence of its staff and authors. The Institute requires that its authors disclose any actual or potential conflicts of interest of which they are aware. Institute staff members are subject to a strict conflict of interest policy.

C.D. Howe Institute staff and authors provide policy research and commentary on a non-exclusive basis. No Institute publication or statement will endorse any political party, elected official or candidate for elected office. The views expressed are those of the author(s). The Institute does not take corporate positions on policy matters.
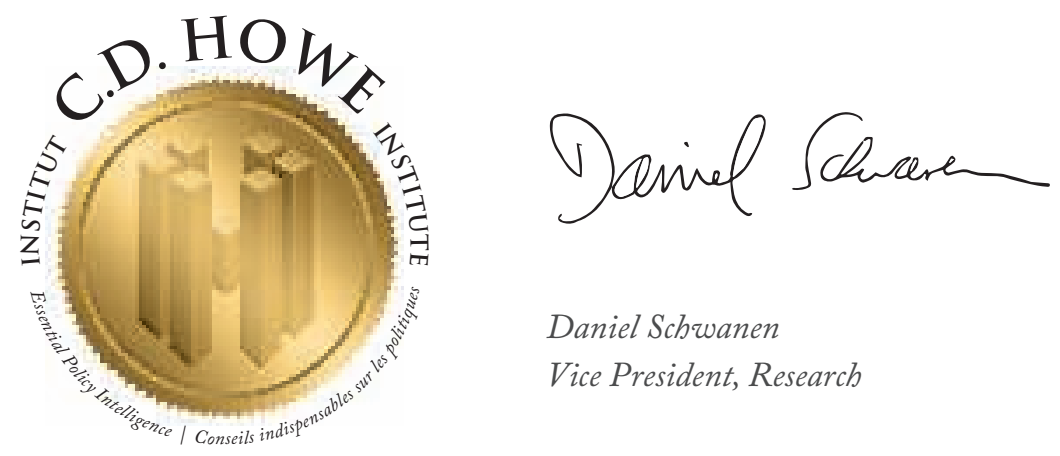

Daniel Schwanen

Vice President, Research 


\section{THE STUDY IN BRIEF}

Equity capital plays an important and growing role in connecting financial resources to investment opportunities in a highly productive manner. Exchange-listed companies, IPOs, venture capital and private equity are all complementary investment avenues. Each plays a vital role that allows companies more efficient access to capital for improving productivity, boosting long-term growth and innovation, and creating better jobs. On this dimension, Canada enjoys an enviable position.

Despite these positive factors, Canada's ranking compared to that of other major economies on key dimensions of competitiveness and drivers of sustainable economic growth has been declining. In 2009-10, Canada ranked ninth on the Global Competitiveness Index; in 2018, it had fallen to twelfth place. More worrisome for the future is that Canada's lacklustre performance in areas known to be significant contributors to productivity, competitiveness and sustainable growth is pervasive across industries and regions.

Although the Canadian financial industry cannot be held responsible for all the shortcomings in Canada's performance, there is no escaping that a disconnect seems to exist between the generally favourable assessment of the effectiveness and strength of the Canadian financial industry and the overall competitiveness of the Canadian economy in the short and long run.

One potential explanation has to do with the median size of exits in Canada, which is almost an order of magnitude smaller than in the United States. Moreover, institutional equity investors often engage in sales to foreign firms rather than IPOs.

One powerful disincentive to exit through public markets is federal government tax policies that discriminate against and penalize Canadian innovative and high-growth companies that "go public." In addition to correcting these counterproductive biases, serious consideration should be given to adopting a tax measure similar to the US Small Business Jobs Act of 2010, which provides for full exemption from federal taxation of capital gains realized on the sale of the shares of certain small businesses. There is empirical evidence that the exemption has had a significantly positive effect in the US.

Serious consideration should also be given to reducing the capital gains tax on shares issued by qualified SMEs when they list on a Canadian stock exchange and are held by individual investors for a reasonable period of time, since evidence suggests that capital gains taxes influence the underpricing of IPOs. The adoption of such a tax measure applicable to exits by an IPO or upon listing the shares on a Canadian stock exchange would help establish a more neutral playground for the choice of exits, which, to a large extent, is the crux of the matter.

C.D. Howe Institute Commentary $($ is a periodic analysis of, and commentary on, current public policy issues. Barry Norris and James Fleming edited the manuscript; Yang Zhao prepared it for publication. As with all Institute publications, the views expressed here are those of the author and do not necessarily reflect the opinions of the Institute's members or Board of Directors. Quotation with appropriate credit is permissible.

To order this publication please contact: the C.D. Howe Institute, 67 Yonge St., Suite 300, Toronto, Ontario M5E 1J8. The full text of this publication is also available on the Institute's website at www.cdhowe.org. 


\section{In a modern economy, economic growth is highly dependent on a financial industry that efficiently allocates capital toward productive investments and encourages investment.}

Growth of gross domestic product (GDP) benefits when the private sector is financed with more equity and less debt, stock market funding expands and credit allocation shifts from household to business loans (Cournède and Denk 2015). On this dimension, Canada enjoys an enviable position.

The market capitalization of Canadian operating companies listed on a Canadian stock exchange equates to about 140 percent of GDP, a level positively correlated with economic growth that reflects financial sophistication (World Bank 2018). ${ }^{1}$ Privately held companies that need external equity to finance their growth have several options. Regardless of their size or stage of development, they can choose to remain private by seeking equity from private investors or access the public market by listing their shares on a stock exchange. In this paper, we refer to private capital as the combination of private venture capital and private equity. The role of private equity is to support businesses' growth beyond the venture stage. Public capital is equity raised by Canadian operating companies in the process of listing their shares or that are listed on either the TSX Venture Exchange or the TSX Exchange.

Over the period between 2013 and June 2018, private equity investors completed deals valued at $\$ 131.3$ billion across all important industry sectors (Table 1). Private venture capital deals totaled
$\$ 15$ billion over this timeframe. During this same period, companies listed on the Toronto Stock Exchange (TSX) raised $\$ 269.9$ billion and those on the TSX Venture Exchange (TSX Venture) \$26.6 billion.

Private companies with a proven business model and a solid management team are the preferred investment target for growth equity firms. Private equity firms fulfill another important function by participating in buyouts, whether purchases of small divisions or subsidiaries of large firms or of entire private or public companies. In the latter case, the motivation is often to restructure and turn operations around. The recent privatization of Canam Group by the Dutil family, with the participation of American Industrial Partners, the Caisse de dépôt et placement du Québec and Fonds de solidarité, is a case in point.

Early-stage companies with high potential for growth but very little or no revenue also have a choice. They may seek a private investment from a venture capital firm or go public. The existence of a thriving public venture market with a long history of facilitating the growth of early-stage companies by providing cost-effective access to equity capital is a unique feature of the Canadian equity market.TSX Venture is one of the world's largest public venture capital markets, and is the "junior" stock exchange with the largest number of graduates on the main

The author thanks Jeremy Kronick, Daniel Schwanen and Farah Omran, members of the Financial Services Research Initiative of the C.D. Howe Institute, and anonymous reviewers for comments on an earlier draft. He retains responsibility for any errors and the views expressed.

1 In 2017, the market capitalization of listed domestic companies relative to GDP was 165.7 percent in the United States and 127.3 percent for member countries of the Organisation for Economic Co-operation and Development (OECD). 


\section{Table 1: Canadian Private Equity Deals by Industry}

2013 - June 2018

\begin{tabular}{|c|c|c|c|c|}
\hline \multirow{2}{*}{ Sector } & & & & \\
\hline & \# Deals & Percent & C\$Millions & Percent \\
\hline Industrial \& Manufacturing & 445 & 18.0 & 14,704 & 11.2 \\
\hline ICT & 334 & 13.5 & 10,517 & 8.0 \\
\hline Life Sciences & 136 & 5.5 & 7,625 & 5.8 \\
\hline Consumer \& Retail & 246 & 10.0 & 20,834 & 15.9 \\
\hline Business Products \& Services & 193 & 7.8 & 7,758 & 5.9 \\
\hline Agri-Forestry & 199 & 8.1 & 5,883 & 4.5 \\
\hline Oil \& Gas, Power & 281 & 11.4 & 34,358 & 26.2 \\
\hline Automotive \& Transportation & 121 & 4.9 & 3,086 & 2.4 \\
\hline CleanTech & 110 & 4.5 & 9,692 & 7.4 \\
\hline Mining \& Resources & 263 & 10.6 & 8,197 & 6.2 \\
\hline Financial & 75 & 3.0 & 3,993 & 3.0 \\
\hline Real Estate & 17 & 0.7 & 1,335 & 1.0 \\
\hline Others & 50 & 2.0 & 3,276 & 2.5 \\
\hline Total & \multicolumn{2}{|c|}{2,470} & \multicolumn{2}{|c|}{$\mathrm{C} \$ 131,258$} \\
\hline
\end{tabular}

stock exchange. ${ }^{2}$ As at December 31, 2018, the total market value of Canadian operating companies listed on TSX Venture stood at $\$ 45.4$ billion.

Although in recent years the availability of venture capital has declined in some peer countries, in Canada the flow of venture capital financing has accelerated. The increase is significant: $\$ 3.8$ billion was invested by venture capital firms in Canada in 2017 compared with $\$ 1.9$ billion in 2013. Today, Canada ranks behind only the United States and Israel in venture capital firm investment as a share of GDP (OECD 2017). In addition, Canadian operating companies listed on TSX Venture raised $\$ 6.4$ billion in 2017 compared with $\$ 3.8$ billion in 2013 (Figure 1).

The apparent dichotomy between private and public equity capital markets as a whole fails to convey the complementary and synergetic relationship between these two primary equity capital market segments. During the 2013-17 period, TSX-listed companies raised $\$ 253$ billion in additional equity capital - in addition to that raised through initial public offerings (IPOs) mostly through the exempt market for private

2 Canada has four stock exchanges. The TSX and Toronto Venture are subsidiaries of the TMX Group, and dominate the markets in their segment on the key dimensions of number of listings, quoted market value and value of trading. The Aequitas NEO Exchange is a new senior exchange that opened for trading in March 2015. Its listings mainly include exchange-traded funds and TSX interlisted companies. The Canadian Securities Exchange is a junior exchange with approximately 300 uniquely listed issuers. 


\section{Figure 1: Public and Private Venture Capital Investment Activity (2013-2017) (C\$Billion)}

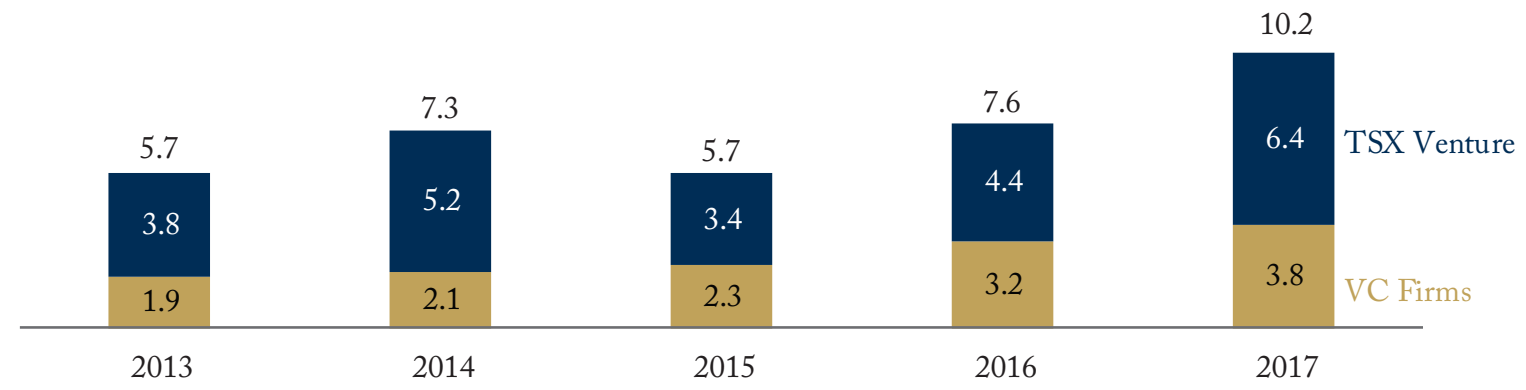

Sources: CVCA VC\&PE Canadian Market Overview (Q3 2018) and TMX MIG Reports.

investments in public equity, while TSX Venturelisted companies raised $\$ 22.9$ billion through the same avenue.

Despite these positive factors, Canada's ranking compared to that of other major economies on key dimensions of competitiveness and drivers of sustainable economic growth has been declining. In 2009-10, Canada ranked ninth on the Global Competitiveness Index; in 2018, it had fallen to twelfth place. More worrisome for the future is that Canada's lacklustre performance in areas known to be significant contributors to productivity, competitiveness and sustainable growth is pervasive across industries and regions (OECD 2003; Stewart and Atkinson 2013):

- Since 1997, both the entry rate of new firms and the proportion of high-growth firms in the Canadian economy have declined by more than 30 percent (Leduc 2017).

- Private sector investment in machinery and equipment is low; estimates for 2018 indicate that Canadian business investment in machinery and equipment hovers around $\$ 13,900$ per worker compared with an average of $\$ 19,700$ and $\$ 23,200$ per worker in OECD countries and the United States, respectively (Robson, Kronick, and Kim 2018).
- The level of business research and development $(\mathrm{R} \& \mathrm{D})$ in Canada is anemic - Canada ranks thirty-third out of $40 \mathrm{OECD}$ and other leading countries - and there has been a sustained erosion in Canada's industrial R\&D capacity and competitiveness (CCA 2018).

Moreover, concerns prevail that promising Canadian companies might not reach the size necessary to assert leadership in global markets, become acquirers of companies themselves and anchor points around which domestic selfsustaining industry-centred ecosystems can emerge. The reason is that Canadian entrepreneurs and investors appear inclined to monetize their investments in start-ups and medium-size companies through the sale of their business to another firm (a "trade sale"), a large majority of which are foreign companies. During the 2001-12 period, 57 percent of trade sales of Canadian companies by private equity and venture capital firms resulted in migration, generally followed by the hollowing out of the company (Carpentier and Suret 2014a). In a nutshell, "the loss of innovative start-ups to foreign buyers, and the inability to grow a sufficient number of start-ups to scale, means that Canadians do not fully capture the social 
and economic benefits stemming from Canadian research advances" (CCA 2018).

Governments in Canada are heavily involved in venture capital (Rémillard 2017), contributing, in part, to its growth over the past decade. ${ }^{3}$ The coexistence of strong private and public equity capital markets is a definite advantage, since it not only increases the amount of equity available to emerging and growing companies; it also augments the number of financing options available to entrepreneurs and business executives. Unfortunately, private equity and venture capital firms, including government agencies and programs that operate in and support private capital firms have a propensity to exit through trade sales, most often to foreign firms, and not through IPOs that lead to the kind of productivity gains and innovations missing from the Canadian economy. Between 2013 and June 2018, private equity firms effected 22 exits through an IPO or reverse takeover (RTO) compared with 390 through a merger and acquisition transaction.

The frequency of IPO exits relative to trade sales is much lower in Canada than is observed in other countries (Breschi, Lassébie, and Menon 2018). A trade sale might indeed be the preferred path of entrepreneurial firms, and there is often sound business reasons to follow this course. Given the comparative record, however, one might harbour reservations about the excuse of financial intermediaries that the decision was out of their control when one observes that the first question most angel investors ${ }^{4}$ or venture capital firm executives ask of a potential portfolio investment is "who are the natural strategic buyers for your company?" If the answer is not convincing, it is likely that the company will not be financed by these private investors. This is not completely disingenuous on their part because knowing the end game gives clarity and alignment with the strategy and helps avoid the "wrong decisions" that will depress returns.

Although the Canadian financial industry cannot be held responsible for all the shortcomings in Canada's performance, there is no escaping that a disconnect seems to exist between the generally favourable assessment of the effectiveness and strength of the Canadian financial industry and the overall competitiveness of the Canadian economy in the short and long run. The role that patient private capital can play in addressing the issue is often overlooked. Appendix A provides examples of private equity investments helping Canadian companies grow their Canadian base. This Commentary examines the dynamics of Canadian public and private capital markets and their efficiency in facilitating access to external equity capital by innovative and high-growth small and medium-sized enterprises (SMEs), as well as their relative performance in assisting those firms scale up and go global. In particular, the need for a better understanding of the determinants of a firm's choice between the exit mechanisms and how to bridge the gap between the financial objectives of private equity and venture capital firms and those of Canada are important policy issues that are absent from public policy statements regarding private capital financing initiatives (Canada 2017).

Given the complementary role played by both public and private equity capital markets, governments need to consider policies that support both and that do not create an impediment to growth when Canadian companies become public. Currently, there is a set of powerful disincentives

3 In 2017, 6 of the 10 most active private equity investors were government agencies or government-sponsored funds. Together, they completed 360 (60 percent) of the 603 private equity deals, and invested $\$ 10.8$ billion (41 percent) of the total private equity investing activity ( $\$ 26.3$ billion) in that year.

4 Wealthy individual investors investing their own funds in start-up companies. Acts as a complement to venture capital funds. 
to exit through the public market, particularly around tax policies. SMEs that "go public" lose their Canadian-controlled private corporation (CCPC) status; ${ }^{5}$ they are penalized by a jump in the federal income rate from 10.5 percent to 15 percent and a substantial decrease in the federal Scientific Research and Experimental Development (SR\&ED) tax credit for R\&D from 35 percent to 15 percent. In addition, when they are listed on an exchange, new technology-based companies are no longer eligible for a cash refund of the SR\&ED tax credit; instead they must content with almost worthless tax credits since, being in the development phase, they are not yet, or barely, profitable.

Furthermore, a sharper focus should be placed on the availability of "permanent" capital - one notes a recent surge in the number of long-term (so-called evergreen) private capital funds in Europe and the United States with fund lives extended by up to 20 years (Lee and Synetos 2018). There is also a need to increase the depth of Canadian equity markets to allow firms to reduce their reliance on foreign investors and improve the chance of remaining independent. To this effect, Canada should consider going the same route as the United States and adopt legislation similar to the Small Business Jobs Act of 2010, which exempts capital gains from federal taxation realized on the sale of shares in certain small businesses held for at least five years prior to sale. Evidence suggests that investment in SMEs thereby increases, as does the number of investors (Edwards and Todtenhaupt 2018).
To encourage the retention of commercialization activities of high-technology and innovative companies in Canada, the federal government should revisit its policy concerning an intellectual property (IP) box tax regime, ${ }^{6}$ implemented in combination with SR\&ED tax credits - a dual approach that European countries have adopted (Boadway and Tremblay 2017). To increase individual investor participation in Canadian stock exchange markets, establish a business need and demand for independent research on small-cap and listed venture companies and increase stock market liquidity for these companies, the capital gains tax for qualifying shares issued by SMEs with less than $\$ 100$ million in assets should be reduced as follows when they become public: the capital gain should be taxed at 50 percent of the current rate if the shares are held for more than 12 months; and the tax rate should be zero if the shares are held for more than 36 months (Chen and Mintz 2011; PwC and FMC Law 2012).

Such a tax incentive structure would not have "perverse" or unwanted effects: investors would profit only if the company in which they have invested progresses and achieves its growth objectives. From the point of view of public finances, the budgetary burden would be extended over time. The beneficial effects of growth would also have to be taken into account, along with the fact that better capitalization would have a positive effect on government revenues, since borrowing costs are a deductible expense for corporate tax purposes. Although many other factors account

5 The small business income corporate tax rate applies to income earned by a CCPC. In general, a corporation is a CPCC if it is a Canadian private corporation, provided it is not controlled by one or more non-resident persons or a public corporation. The general corporate rate of 15 percent applies to active business income earned in excess of $\$ 500,000$. A CCPC is eligible to claim the 35 percent input tax credit rate and related 100 percent input tax credit refund on current expenditures (up to an expenditure limit of $\$ 3$ million) as long as prior year taxable capital does not exceed $\$ 50$ million or taxable income exceeds $\$ 800,000$ (on an associated group basis).

6 IP boxes are tax regimes that provide a reduced rate of tax income arising from the license or use of IP. In contrast to existing R\&D tax incentives that provide an income tax incentive at the front end of the process, IP boxes provide a backend tax reduction for successful innovations. The vast majority of countries with IP boxes also provide R\&D tax credits or enhanced deductions for R\&D expenditures (Merrill 2016). 
for their performance, Switzerland, which ranked as the world's most competitive economy for nine consecutive years up until 2018, does not levy capital gains tax on the sale of company shares by its residents, nor does Singapore, which ranked second in 2018 and ranks consistently among the five most competitive economies. ${ }^{7}$

\section{THE DATA}

The analysis in this Commentary is based, in part, on the information concerning Canadian private equity deals provided the Canadian Venture and Private Equity Association (CVCA) by Participating Data Contributors for the 2013-June 2018 period. The CVCA classifies private equity deals as follows:

- a buyout deal is investment for the control of a portfolio company, including platform creation secondary buyout;

- a growth deal is significant minority investment in a portfolio company through new capital infusion and recapitalization;

- an $a d d-o n$ deal is a corporate acquisition by a majority-controlled, private-equity-backed portfolio company;

- a debt deal is debt investment in a portfolio company; and

- an infrastructure deal is investment in the development and management of infrastructure assets, but where private equity does not own the underlying assets.

Venture capital deals, in contrast, include equity or quasi-equity deals only, not non-equity or project-based government funding, pharmaceutical development deals, senior debt, venture-capitalbacked acquisitions or angel financing. Venture capital development stages are delineated as follows:
- the seed stage, where the company has a concept or product under development, but is probably not fully operational;

- the early stage, where the company has a product or service in testing or pilot production, in some cases, the product may be commercially available; and

- the later stage, where the product or service is in production and commercially available, and the company is generating on-going revenue, but is not necessarily profitable.

The CVCA database of private capital deals identifies the investor firm and its location, the investors, the dates of announcement and conclusion of the deal, the type of deal, the industrial sector and the amount of the transaction, when this information is available.

Also obtained, from TMX Group, which owns the TSX and TSX Venture, were lists of IPOs completed on the TSX and TSX Venture by newly listed firms during the 2013 - June 2018 period. The lists identify the issuers, their headquarters location, their industry sector, the offering price, the number of securities issued and the date and gross proceeds of the transactions. This information is supplemented with that contained in the Market Intelligence Group Reports published monthly by TMX Group and in Thomson Reuters' Canadian Venture Capital Review.

\section{The Geography of Canadian Private Equity Deals}

Worldwide, capital flows are concentrated in metropolitan areas where the investment benefits from the externalities of urban agglomeration such as technological spillovers, greater productivity gains and increasing returns to scale generated by

7 Canada ranked twelfth in 2018, in line with its average competitiveness ranking for the 2007-18 period; in 2018, Switzerland ranked fourth (Schwab 2018). 
Table 2: Distribution of Number and Value of PE Deals across Canada, 2013-June 2018

\begin{tabular}{|c|c|c|c|c|c|}
\hline & \multicolumn{2}{|c|}{ Volume of PE Deals } & \multicolumn{2}{|c|}{ Value of PE Deals } & \multirow{2}{*}{$\begin{array}{c}\text { Percent of } \\
\text { Canada's GDP } \\
2016\end{array}$} \\
\hline & (Number) & (Percent) & (C\$Billion) & (Percent) & \\
\hline Alberta & 346 & 14.0 & 32.3 & 24.6 & 15.5 \\
\hline British Columbia & 255 & 10.3 & 9.8 & 7.5 & 13.0 \\
\hline Manitoba & 27 & 1.0 & 1.3 & 1.0 & 3.3 \\
\hline New Brunswick & 11 & - & 0.3 & - & 1.7 \\
\hline Newfoundland & 6 & - & 0.1 & - & 1.5 \\
\hline Nova Scotia & 19 & 1.0 & 0.3 & - & 2.0 \\
\hline Ontario & 535 & 21.7 & 54.6 & 41.6 & 39.0 \\
\hline Prince Edward Island & 3 & - & - & - & 0.3 \\
\hline Québec & 1,198 & 48.5 & 30.6 & 23.3 & 19.4 \\
\hline Saskatchewan & 70 & 3.0 & 2.0 & 1.5 & 3.7 \\
\hline Total & 2,470 & & 131.3 & & \\
\hline
\end{tabular}

the clustering of economic activity (Melo et al. 2016). The distinctive and competitive advantages of major metropolitan agglomerations stem from the presence of large firms and service providers and a strong infrastructure of universities, advanced research laboratories, business incubators and institutional sources of start-up and growth capital. Combined with their size, these agglomerations offer entrepreneurs greater market opportunities and facilitate their access to networks that embody large volumes of advanced and market knowledge and vast expertise. These are propitious conditions for the creation of high-tech firms and fertile grounds for venture capital and private equity firms.
The geography of Canadian-reported private equity deals conforms to this global trend: 86.4 percent of the disclosed deals were completed with firms located in one of Canada's ten largest metropolitan areas, nearly 58 percent of them in Toronto and Montreal. Together, the populations of Alberta, British Columbia, Ontario and Québec represent 86.3 percent of Canada's total and produce 86.9 percent of the country's gross national product. Their share of private equity deals is slightly higher: 94.5 percent of total deals and 97.0 percent of the total amount of financings (Table 2). Consistent with the findings that private equity and venture capital firms are much more 


\begin{tabular}{|c|c|c|c|c|c|c|}
\hline Size of Deal & $\begin{array}{l}\text { Number of } \\
\text { Deals }\end{array}$ & Scenario 1 & Scenario 2 & Scenario 3 & Scenario 4 & Scenario 5 \\
\hline Over $\$ 1$ billion & 82 & $10(12)$ & $5(6)$ & $7(9)$ & $57(69)$ & $3(4)$ \\
\hline$\$ 500$ million to $\$ 1$ billion & 68 & $14(20)$ & $4(6)$ & $7(10)$ & $39(57)$ & $4(6)$ \\
\hline $\begin{array}{l}\text { Sample of deals from } \$ 100 \\
\text { to } \$ 500 \text { million }\end{array}$ & 41 & $17(41)$ & $4(10)$ & $4(10)$ & $12(29)$ & $4(10)$ \\
\hline $\begin{array}{l}\text { Sample of deals under } \$ 100 \\
\text { million }\end{array}$ & 41 & $25(61)$ & $11(27)$ & $0(0)$ & $4(10)$ & $1(2)$ \\
\hline \multicolumn{7}{|c|}{$\begin{array}{l}\text { Scenario 1: Investment by Canadian PE in the primarily Canadian operations of a Canadian (or sometimes foreig } \\
\text { Scenario 2: Investment by Canadian or foreign PE in Canadian business expanding or operating internationally. } \\
\text { Scenario 3: Foreign PE investors acquiring a Canadian business, or merging it with a foreign business. } \\
\text { Scenario 4: Canadian PE investor investing in (or selling stake in) international companies not based in Canada. } \\
\text { Scenario 5: Investment by Foreign PE in a primarily Canadian business. }\end{array}$} \\
\hline Source: Canadian Venture an & Private Equity & sociation. & & & & \\
\hline
\end{tabular}

likely to fund entrepreneurs located within a short geographic distance from where they are based (Sorenson and Stuart 2001), the incidence of cross-province transactions by Canadian private equity firms is very low. It is also noteworthy that, out of the total number of private equity deals, 654 (26.5 percent) consisted of debt rather than equity as such.

The number of private equity deals completed in Québec during the study period far exceeded the province's economic weight within Canada, although, in terms of value, the proportion was only slightly higher than Québec's share of Canada's GDP (Table 1; see also Box 1). This indicates that, on average, the financing amounts were much smaller than in the rest of Canada (about one-fifth of the size of Ontario's private equity deals and one-quarter of Alberta's). A striking particularity of the Québec scene is that 535 of the 1,198 private equity deals were debt financings, representing 45 percent of all private equity deals completed in the province and 82 percent of the total number of Canadian private equity transactions involving debt rather than equity.

\section{The Characteristics of Canadian Private Equity Deals}

Private equity deals can be characterized as falling under one of five possible scenarios described in Table 3.

The breakdown reveals that: (i) smaller deals overwhelmingly focused on capital for Canadian companies to grow in Canada or internationally (Scenarios 1 and 2); (ii) mid-sized deals involved a more diversified mix of purposes, including proportionately more acquisitions or stakes by foreign investors in Canadian companies than do deals of other sizes (with Scenarios 3 and 5 composing twenty percent of the deals); and (iii) larger deals involved proportionately more Canadian investors buying foreign companies than did deals of other sizes.

Examples of Scenario 2 deals that helped Canadian companies grow abroad and become world leaders in their sectors are exemplified by private placements by the Caisse de dépôt et placement du Québec in Group WSP Global Inc. to support its acquisition of the US-based engineering firm Parsons Brinckerhoff Group 


\section{Table 4: Industry Concentration of PE Deals According to Size of PE Deals}

\begin{tabular}{|c|c|c|c|}
\hline \multirow{2}{*}{ Industry } & \multicolumn{3}{|c|}{ Relative Concentration of Private Equity Deals } \\
\hline & $\begin{array}{c}\text { Large } \\
\text { (over \$ } 1 \text { billion) }\end{array}$ & $\begin{array}{c}\text { Mid-size } \\
\text { (\$500 million-\$1 billion) }\end{array}$ & $\begin{array}{c}\text { Smaller } \\
\text { (less than } \$ 500 \mathrm{M})\end{array}$ \\
\hline Auto and Transport & $\mathrm{X}$ & $\mathrm{X}$ & \\
\hline Real Estate & $\mathrm{X}$ & $\mathrm{X}$ & \\
\hline Business products and Services & $\mathrm{X}$ & & \\
\hline Clean Tech & $\mathrm{X}$ & & \\
\hline Financial & $\mathrm{X}$ & & \\
\hline Consumer and Retail & & $\mathrm{X}$ & \\
\hline Oil and gas and Power & & $\mathrm{X}$ & \\
\hline Agriculture and Food & & & $\mathrm{X}$ \\
\hline ICT & & & $\mathrm{X}$ \\
\hline Industrial and Manufacturing & & & $\mathrm{X}$ \\
\hline Life Sciences & & & $\mathrm{X}$ \\
\hline Mining & & & $\mathrm{X}$ \\
\hline
\end{tabular}

\section{Box 1: Entrepreneurial Finance with Québec Characteristics}

Explaining the peculiarity of this type of private equity financing in Québec compared to other provinces is not straightforward, especially in the context where the stated mission of the financial intermediary is to support innovation and rapid business growth. The provisions of the Québec Civil Code governing the priorities, rights and obligations of secured or hypothecary creditors, including the right of a secured creditor following a default by the debtor, are not so different in their effect as those applicable in other provinces to explain the wide difference in the type of private equity financing. Desjardins Capital participated in 63 percent of these debt deals, while the labour-sponsored Fondaction CSN accounted for 19 percent.

The concentration of these debt deals in two institutions suggests that the practice reflects institutional culture and preferences, not an inhospitable legal environment for private equity investment. Moreover, these private equity debt financings were relatively small and spread across all regions and, therefore, less concentrated in metropolitan areas than other types of private equity financings. In a nutshell, a large proportion of these private equity debt deals seem to be bank financing by another name. 
Inc. (\$200 million), in Group CGI to assist in financing the acquisition of UK-based Logica PLC ( $\$ 1.0$ billion) and its US $\$ 315$ million investment in Cogeco Communication's US subsidiary to facilitate the US\$1.4 billion acquisition of MetroCast, a US cable distributor. It should be noted that all these major private placements were made in public companies, which clearly reflects the complementarity nature of the private and public equity markets.

There is also a correlation between the size of deals and the industry sector. Table 4 shows the industries that are overrepresented in each deal size category relative to the universe of private equity deals. One notes the financial support that smaller deals bring to the high growth/high productivity sectors of Canada's economy, based on sciences and engineering as well as some areas of traditional comparative advantage such as food and mining.

\section{THE CANADIAN STOCK EXCHANGE MARKET}

The significant decline in the number of exchange-listed firms in the United States since the mid-1990s has led many to suggest that the phenomenon has spread to Canada (see, for example, Tingle, Pandes, and Robinson 2013). The blame for the evanescing number of IPOs in the United States was first attributed to the substantial costs arising from the mandated regulations of the Sarbanes-Oxley Act of 2002, which imposed a heavy burden on public companies and a disproportionate one on US companies of the size typical of the vast majority of publicly traded Canadian companies. ${ }^{8}$

The Paulson Report (Committee on Capital Markets Regulation 2006) documents well the regulatory overreach, and confirms the assessment by most market participants and legal scholars that Sarbanes-Oxley's changes to the legal regime were ineffective and too costly (Bainbridge 2010; Romano 2005). Thanks to the polycentric structure of Canada's securities regulatory system, Canadian companies have been spared this unnecessary burden despite pressure from some securities regulators and powerful lobby groups to import the original US regulatory changes (Lortie 2010).

It is undisputable that, since 2010, the number of Canadian operating companies listed on the TSX and TSX Venture has decreased by 229 and 405 , respectively (Figure 2). A careful examination of the phenomenon leads to the conclusion that the decline was not caused by the emergence of alarming structural issues, but, to a large extent, was a direct consequence of the depressed conditions that prevailed during this period in the global mining and oil and gas sectors.

As at December 31, 2018, 707 Canadian operating companies were listed on the TSX and 1,468 on TSX Venture. Reflective of the structure of the Canadian economy and the inability to finance mineral exploration and deposit appraisal work phases by other means than equity because of the lack of collateral, Canadian companies in the mining and oil and gas sectors accounted for close to 41.0 percent of TSX Canadian-listed operating companies and 74 percent of those on TSX Venture. ${ }^{9}$ A large proportion of these

8 A detailed analysis of the US listings gap suggests that delistings are a major explanation of the drop in listings. The high number of mergers that occurred in the United States after 1996 is seen as a major cause (Doidge, Karolyi, and Stulz 2017). Other studies lend support to this conclusion. On a number of measures, US markets are more concentrated and less open to competition today than they were a few decades ago, partly due to increased merger and acquisition activity (Guetierrez and Philippon 2018).

9 In terms of capitalization, on December 31, 2018, Canadian natural resources firms represented 57.5 percent of the quoted market value of Canadian operating companies on TSX Venture and 21 percent of the quoted market value of those on the TSX. 


\section{Figure 2: Number of Listed Canadian Operating Firms, 2010 - September 2018}

TSX Venture (\#)

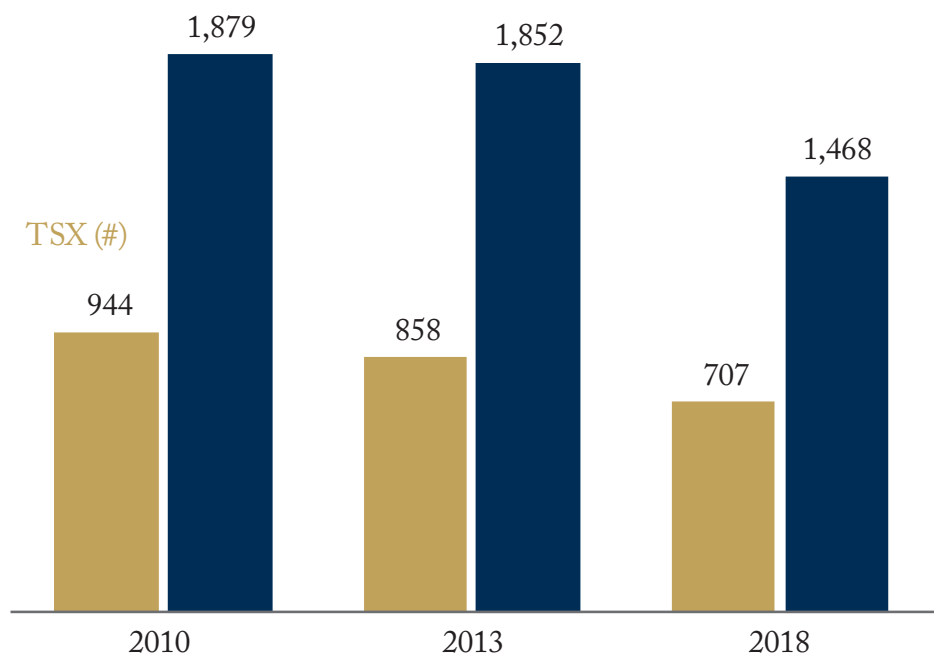

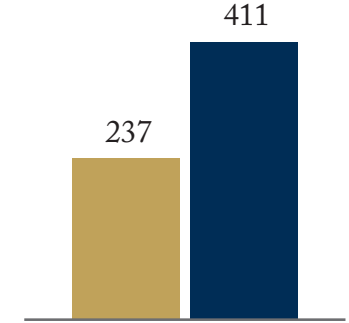

$\Delta 2010-2018$

Source: TMX MIG Reports.

companies are exploration and junior development companies that traditionally have resorted to public equity markets to finance their activities to obviate the absence of classic venture capital financing in this sector. Variations in the volume of their activities are strongly correlated with price trends. Accordingly, slumps in mineral commodity prices and negative global market conditions have a direct and depressing effect on the number of listed natural resources companies. From their historic highs in 2011, mineral and metal prices followed a path of persistent decline that lasted until 2016 (Bank of Canada 2018). Energy markets were also depressed. Not surprisingly, between December 2010 and December 2018, the number of natural resources companies listed on the TSX and TSX Venture fell by 185 and 360, respectively, accounting for 84 percent of the decline in listed operating companies.

The focus on the Canadian IPO market as a bellwether for the perceived erosion of the role of the public stock exchange market as the key mechanism for access to and pricing of equity capital fails to recognize that the motivations spurring the decision to "go public" and list on a stock exchange extend beyond a desire to raise equity. Surveys of chief executive officers of public companies reveal that the ability to use their publicly traded shares as a currency to acquire other companies and assets is one of the main advantages they associate with being public (Lowry, Michaely, and Volkova 2017; PwC and FMC Law 2012). Although it might not always be perceived as such, the imprimatur provided investors and lenders by the continuous scrutiny of public companies exercised by a stock exchange and by securities regulators greatly facilitates repeat access to equity and debt financings and the diversification of financial sources to support growth or make acquisitions. Other key advantages that $\mathrm{CEO}$ have cited include the fact that being listed on an exchange allows them to use the price of their 
publicly traded shares to value stock options and that it facilitates the establishment of incentive programs for employees and the recruitment of better-qualified executives and employees. Being a listed public company is also considered an effective marketing tool, a status that gives visibility, a strengthened image within the financial community and comfort to customers, suppliers and governments.

The above suggests that, in addition to raising cash, a major benefit derived from an IPO stems from the fact that the issuing company becomes a public company and that listing on an exchange follows automatically. To the extent that listing on an exchange can be achieved through other avenues, it is the end result that should be considered, not how the company got there. In Canada, due consideration needs to be given to three major characteristics of the stock exchange market: (i) the number of methods other than an IPO available to Canadian companies seeking to become public with shares listed on the TSX or TSX Venture; (ii) the massive amount of equity financing done by Canadian companies listed on the TSX and TSX Venture through subsequent public offerings and private placements; and (iii) the role of TSX Venture as a feeder of new listings on the TSX.

\section{An Adapted Regulatory Framework}

In Canada, the regulatory framework has been adapted to allow stock exchanges to implement mechanisms that bypass the traditional IPO route in order to facilitate the "going public" process (see Table 5).

The Capital Pool Company (CPC) program is a unique mechanism for listing on TSX Venture. The program allows a newly created private company that has no assets other than cash and no commercial operations to conduct an IPO in order to raise start-up capital and list its securities

\section{Table 5: Alternate Methods for Accessing Public Equity Markets}

TSX

TSX Venture

Special purpose acquisition vehicle (SPAC)

Capital Pool Company (CPC)

Reverse Takeover (RTO)

Reverse Takeover (RTO)

Source: Author's compilation.

for trading on the exchange. Once the IPO is completed, the CPC has 24 months to identify and acquire a business or pool of assets using the funds raised from the issuance of its seed shares and from the IPO. The acquisition is called a qualifying transaction, and the exchange requires that following the acquisition, the resulting issuer must meet TSX Venture's applicable minimum listing requirements. Although these equity financings are not technically considered to be IPOs, they essentially fulfill the same function. As at December 31, 2018, there were 110 CPCs listed on the TSX Venture with $\$ 146$ million in equity capital available to companies seeking to list on the TSX Venture, while bypassing the IPO route. The CPC program is considered a success since: (i) more than 90 percent of CPCs complete a qualifying transaction within the prescribed time frame; (ii) it is used by early-stage companies drawn from all industries, and (iii) almost 30 percent of currently TSX-listed graduates are former CPCs (Nassr and Wehinger 2016; TMX 2015).

Another mechanism is the Special Purpose Acquisition Company program, which is somewhat similar to a CPC. As at December 31, 2018, the one such company listed on the TSX had \$403 million available for qualifying acquisition transactions with companies seeking to list on the TSX. To date, this financing option has been used very sparingly. Companies may also be listed on either the TSX 
or TSX Venture by completing an $\mathrm{RTO}^{10}$ of an existing listed issuer whereby a company that is publicly listed on a stock exchange but that has few if any assets acquires all of the securities of a private company that has substantial assets and/or operations, resulting in the latter's indirectly "going public."The public company acquires the securities of the private company by issuing to the private company's shareholders a significant number of shares in the public company equivalent in value to the assets or operations of the private company.

\section{Expedited Access to Equity Markets}

Stock exchange-listed companies are subject to rules and regulations to ensure that sufficient and timely information is made available to investors. Directors and officers of companies who knowingly provide false or delayed information are liable to harsh penalties. These conditions are essential to ensure an information-efficient capital market; they also lead to improved governance and accountability practices. Confidence that disclosure of relevant and material information by listed companies is accurate, credible and timely greatly simplifies the investment decision-making process of investors and improves capital flows. This is confirmed by strong evidence: between 2010 and 2018, the proceeds of IPOs represented 12 percent of the total equity raised by TSX-listed companies; on TSX Venture, the ratio was 4 percent (Tables 6 and 7). A similar situation is observed in the United States, where private investment in public equity by private equity firms has become a favourable financing option for exchange-listed companies.

\section{Feeding Listings to the TSX}

An important measure of the success of TSX
Venture as a "second market" is the number of companies listed on that exchange that grow and graduate to the TSX once they satisfy the latter's listing requirements. Since 2010, 206 TSX Venture companies have graduated to the TSX, compared with 141 that have obtained listing through a traditional IPO (Table 8). It is noteworthy that almost 20 percent of the S\&P/TSX Composite Index and over 10 percent of TSX-listed companies with a market capitalization greater than $\$ 1$ billion are TSX Venture graduates (TMX 2015). This is in contrast with the experience in continental Europe, where the incidence of graduation is almost nil.

\section{COMPLEMENTARITY BETWEEN CANADA'S EQUITY CAPITAL MARKETS}

TSX Venture has proved to be a formidable venue to facilitate SMEs' access to equity capital, notably in the years leading up to the expansion of private equity capital markets in Canada. Companies listing their shares on TSX Venture are generally new business ventures with minimal sales and assets. About half of them do not report any income; they chose to go public at a stage where venture capital firms show little, if any, interest in them. Figure 3 shows the amounts of venture capital invested by such VC firms and the amounts of equity raised by TSX Venture-listed operating companies in sectors other than mining and mineral fuels. Taken together, venture capital investments in Canadian non-mineral resources companies grew from approximately $\$ 3.1$ billion in 2013 to $\$ 6.0$ billion in 2017.

The complementarity between the public and private equity markets is most pronounced in the financing of Canadian mineral resources companies (Figure 4) - sectors that accounted

10 The drawback of RTO transactions is that they are subject to statutory requirements for the holding of shareholder meetings and regulatory approvals. In addition, companies resulting from the RTO may inherit actual or contingent liabilities for actions (or lack thereof) by the shell company. 
Table 6: Equity Financings by TSX Listed Companies

\begin{tabular}{|c|c|c|c|c|c|}
\hline & IPO & $\begin{array}{c}\text { Subsequent Public } \\
\text { Offerings }\end{array}$ & $\begin{array}{c}\text { Private } \\
\text { Placements }\end{array}$ & Total & $\begin{array}{l}\text { Total Number of } \\
\text { Financings }\end{array}$ \\
\hline & \multicolumn{4}{|c|}{ (C\$Million) } & \\
\hline 2010 & 10,701 & 26,839 & 6,609 & 44,149 & 780 \\
\hline 2011 & 6,608 & 31,097 & 3,283 & 40,988 & 711 \\
\hline 2012 & 4,258 & 37,718 & 7,586 & 49,562 & 723 \\
\hline 2013 & 5,454 & 30,125 & 4,280 & 39,859 & 599 \\
\hline 2014 & 5,426 & 41,662 & 5,459 & 52,547 & 557 \\
\hline 2015 & 6,728 & 38,998 & 8,654 & 54,380 & 557 \\
\hline 2016 & 1,543 & 52,102 & 4,106 & 57,751 & 631 \\
\hline 2017 & 6,047 & 32,912 & 9,461 & 48,420 & 658 \\
\hline \multirow[t]{2}{*}{2018 (H1) } & 2,738 & 20,960 & 10,330 & 34,028 & 525 \\
\hline & 49,503 & 312,413 & 59,768 & 421,684 & 5,741 \\
\hline
\end{tabular}

\section{Table 7: Equity Financings by TSX Venture Listed Companies}

\begin{tabular}{|c|c|c|c|c|c|}
\hline & IPO & $\begin{array}{c}\text { Subsequent Public } \\
\text { Offerings }\end{array}$ & $\begin{array}{c}\text { Private } \\
\text { Placements }\end{array}$ & Total & $\begin{array}{l}\text { Total Number of } \\
\text { Financings }\end{array}$ \\
\hline & \multicolumn{4}{|c|}{ (C\$Million) } & \\
\hline 2010 & 333 & 3,107 & 6,392 & 9,832 & 2,603 \\
\hline 2011 & 291 & 2,985 & 6,820 & 10,096 & 2,252 \\
\hline 2012 & 150 & 1,826 & 3,984 & 5,960 & 1,894 \\
\hline 2013 & 119 & 866 & 2,780 & 3,765 & 1,582 \\
\hline 2014 & 119 & 1,376 & 3,737 & 5,232 & 1,572 \\
\hline 2015 & 544 & 744 & 2,557 & 3,845 & 1,279 \\
\hline 2016 & 33 & 977 & 3,398 & 4,408 & 1,549 \\
\hline 2017 & 97 & 1,825 & 4,180 & 6,102 & 1,564 \\
\hline \multirow[t]{2}{*}{2018 (H1) } & 71 & 2,061 & 4,665 & 6,797 & 1,701 \\
\hline & 1,757 & 15,767 & 38,513 & 56,037 & 15,996 \\
\hline
\end{tabular}


Figure 3: Venture Investments in Canadian Non-mineral Resources Companies, (C\$Billion)

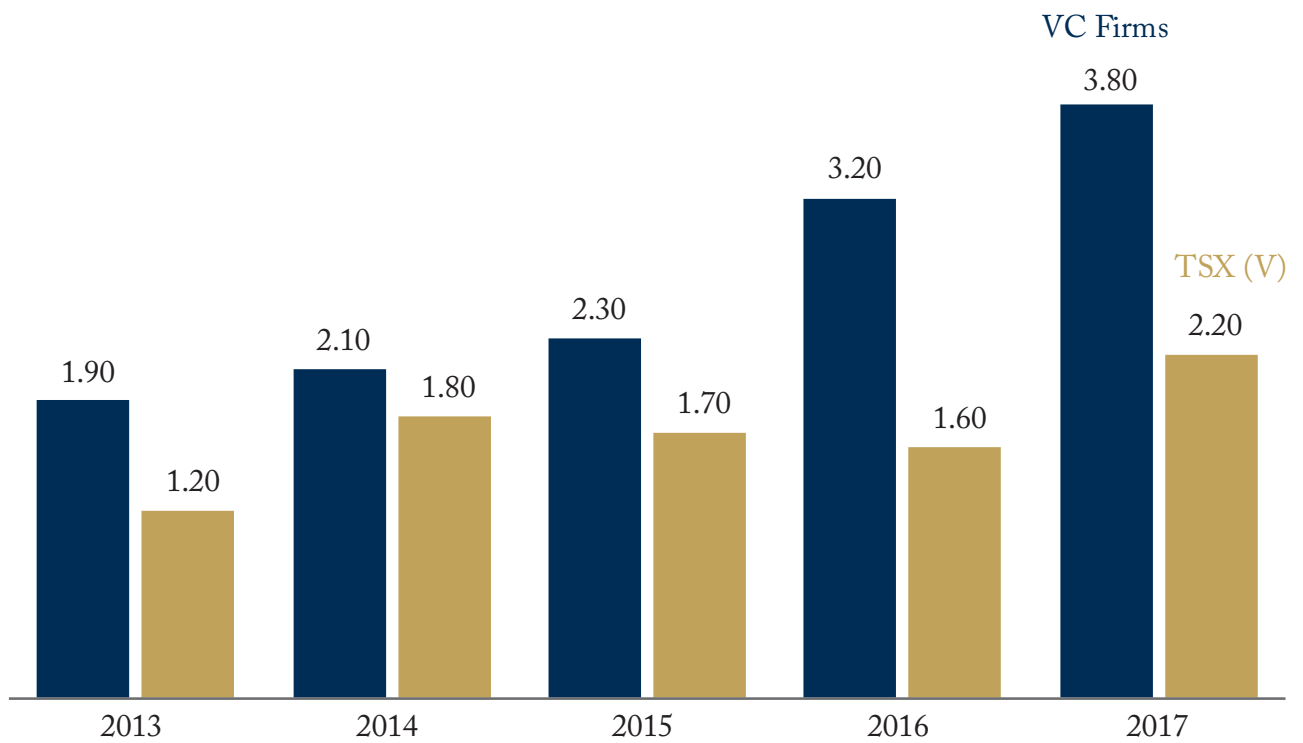

Source: CVCA database.

for about 39 percent of the value of Canadian goods exports in 2017. Canada's varied geology results in a pronounced concentration of different types of mineral resources in specific regions of the country. It is therefore an important source of wealth creation, often in impoverished and remote areas. Mineral exploration is thus essential to the long-term viability of Canada's mining and oil and gas industries. Junior mining companies play an important role in the discovery and development of mining projects because their activities focus on offmine-site exploration and deposit appraisal work phases, while senior mining companies generally focus on on-site exploration and appraisal activities. Although this separation of tasks is less pronounced in the oil and gas sector, it remains an important aspect of the industry. The development of fracking technology and the growth of shale oil and gas production in North America is a case in point.

Mining exploration and deposit appraisal expenditures in Canada amounted to $\$ 1.6$ billion in 2016 and were expected to total $\$ 2.2$ billion in 2018 (NR Can 2018). Since 2010, junior mining

\begin{tabular}{lcc|}
$\begin{array}{l}\text { Table 8: Source Of New Tsx Canadian Company } \\
\text { Listings }\end{array}$ & $\begin{array}{c}\text { TSX IPO* } \\
(\#)\end{array}$ & $\begin{array}{c}\text { TSX Venture } \\
\text { Graduates } \\
(\#)\end{array}$ \\
\hline 2010 & 39 & 40 \\
\hline 2011 & 19 & 45 \\
\hline 2012 & 13 & 27 \\
\hline 2013 & 19 & 20 \\
\hline 2014 & 8 & 22 \\
\hline 2015 & 13 & 9 \\
\hline 2016 & 3 & 16 \\
\hline 2017 & 17 & 15 \\
\hline 2018 (Sept.) & 10 & 12 \\
\hline & 141 & 206 \\
\hline * Excludes ETFs, SPs, SPACs. & \\
\hline Source: TMX MIG Reports. & & \\
\hline
\end{tabular}




\section{Figure 4: Private and Public Venture Capital Investment in Mineral Resource Companies, (C\$Billion)}

TSX (V)

3.9

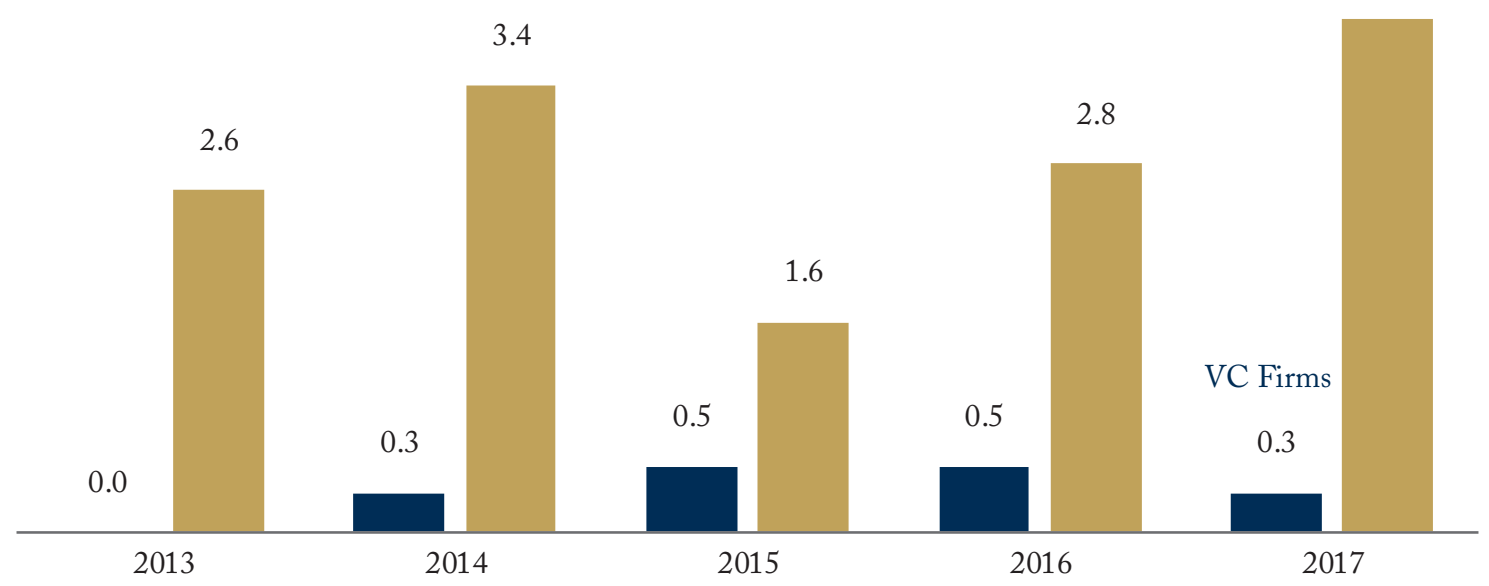

Sources: CVCA database; TMX MIG Reports.

companies have accounted for about 45 percent of total exploration and deposit appraisal expenditures in Canada. Such a structural feature of the industry has two main consequences. First, it has a major effect on the form of financing of junior companies' exploration and development activities. Due to the nature and high risks of their activities, they do not have access to bank financing or to internal sources of revenue. Second, since exploration companies operate off-site, their discoveries lead to new mines along with the major investments needed to bring them into production.

Junior mining companies have long played an important role in bringing Canada's mineral deposits into production. Diamond mining is a good example of the contribution of mining exploration companies to wealth creation. Until the late 1990s, diamond mining was virtually non-existent in Canada. Most people considered it a fantasy that Canada could become a major producer of natural gem-quality diamonds. Yet, since 2006, Canada has been the world's third-largest producer of natural diamonds. The six large-scale diamond mines operate to the highest human rights and environmental standards in the world. In 2017, their total primary exports of diamonds were valued at $\$ 2.6$ billion. Their activities are also an important source of employment and income for people living in remote northern communities. Other recent mineral exploration successes include Osisko Mining (Canadian Malartic - gold), Consolidated Iron Mines (Lac Bloom - iron ore) and Virginia Gold Mines, which discovered the Éléonore gold project in the James Bay region and which Goldcorp developed at a cost exceeding $\$ 1.4$ billion. All these companies first listed their shares on TSX Venture before graduating to the TSX. Figure 5 shows the number of mining and oil and gas companies listed on the TSX and TSX Venture and their quoted market value (QMV) at December 31, 2018.

Steeped in TSX Venture's long tradition of financing mining exploration and development companies, those listed on the exchange raised \$13.1 billion in equity capital over the 2013-18 period, while the mining companies listed on the TSX raised $\$ 27.2$ billion. In the oil and gas 


\section{Figure 5: Mining and Oil \& Gas Companies Listed on the TSX and TSX Venture at 30 September}

\section{8}

Number

QMV (C\$billion)
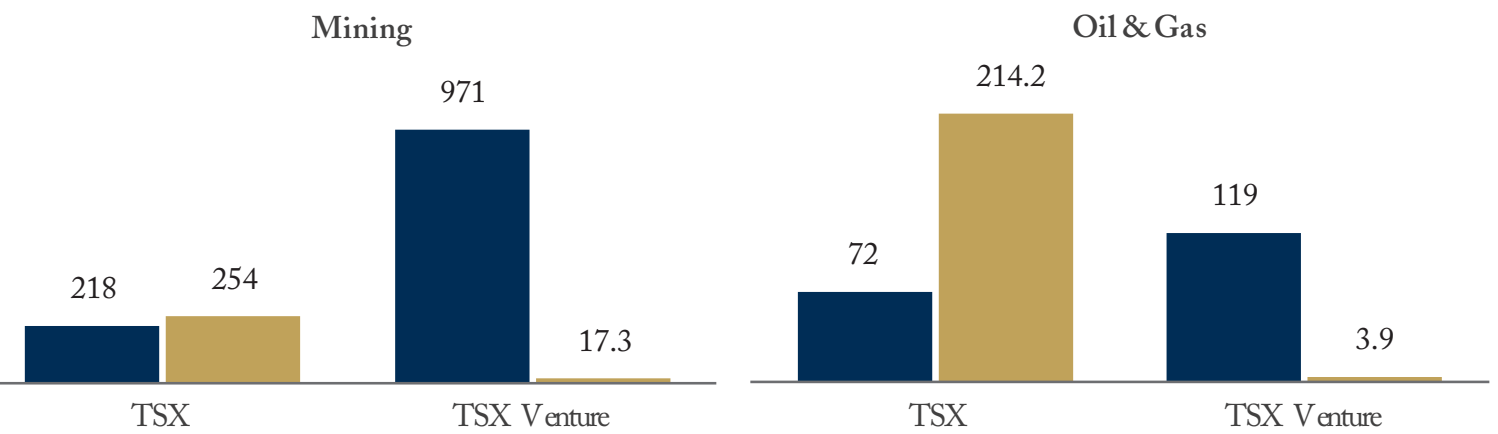

Source: TMX MIG Reports.

sector, the companies listed on TSX Venture raised $\$ 4.9$ billion and those listed on the TSX $\$ 38.3$ billion. Private equity and venture capital firms are seldom involved in the financing of TSX Venture-listed mining and oil and gas companies, preferring more mature companies that have reached the construction or production phase. ${ }^{11}$ Between 2013 and 2018, total investment in the 263 private equity deals completed with a mining and resources company amounted to $\$ 8.2$ billion, of which 151 (57 percent) were completed in Québec. In addition, 281 private equity deals were completed with oil and gas companies, for a total of $\$ 34.4$ billion; 223 (81 percent) of these deals were completed in Alberta.

\section{TSX VENTURE CHALLENGES}

The TSX Venture Exchange now faces competition from a dynamic private venture capital investment industry. Venture capital firms account for an increasing share of the flow of venture capital invested in non-mineral resources companies. During the 2013-17 period, venture capital firms invested a larger amount of equity capital in nonmineral resources companies than the amounts raised through public venture capital ( $\$ 13.3$ billion versus $\$ 8.5$ billion). To maintain its share of the venture equity market, TSX Venture will have to deal with the erosion of its ability to attract new listings, which stems in part from the intrinsic characteristic of SMEs: their size. In December

11 A comparison of the list of private equity deals reported by the CVCA for the period between 2013 and August 2018 with the list of IPOs completed by TSX Venture issuers during the same period identifies only three companies in which a private equity firm was involved: one in metal/mining, one in oil and gas and one in cannabis! 
2018, the average QMV of companies listed on TSX Venture was approximately $\$ 30$ million.

Trading activity on TSX Venture historically has been dominated by retail investors, and remains so. ${ }^{12}$ The participation of institutional investors is constrained by regulatory and liquidity considerations that generally limit the size of their equity participation in public companies to less than 10 percent of a company's QMV. The constraint this limit imposes on them is obvious: 10 percent of a company with a market capitalization of $\$ 10-\$ 30$ million means an investment of \$1-\$3 million, well below the common institutions' minimum listed equity portfolio threshold for such investments.

Liquidity - the ability to trade a security quickly at the posted price - is one of the most important factors in determining the price of a security. Obviously, the greater the market value of a company and the greater the number of shareholders, the more liquid the market for its shares will be. A recent study found that junior stock markets generally have about 30 percent of the liquidity of the senior markets (Peterhoff, Romeo, and Calvey 2014). Since liquidity is critical to the efficiency of a market, exchanges have instituted specialist or market-maker systems to provide market liquidity whereby these firms are required to buy or sell securities at the posted prices in the absence of a third party. This mechanism is designed to guarantee a two-way market for a security on a continuous basis, and ensure that share prices are not unduly influenced by patterns of buy or sell orders. Firms acting as market makers must devote a substantial amount of capital to this activity. Generally, investment banks and brokerage firms specializing in the public financing of SMEs do not commit the financial and human resources required or implement the tight risk controls necessary to perform this regulated function.

The "tick size" - the smallest movement at which securities can be bought or sold on an exchange - is a determinant of the profits earned by market makers that provide counterpart services on demand for investors trading through the exchange. The TSX's adoption of decimalization and the reduction of the tick size imposed over the years ${ }^{13}$ have reduced economic incentives to engage in market-making activities, particularly for listed securities with a low price and small volume of trading (Chin and Garriott 2016). In addition, with the introduction of high-frequency trading (HFT) technologies, bid-offer spreads have narrowed and the average size of trades has declined. On TSX Venture, HFT firms account for about 55 percent of all orders for the securities they trade (Malinova and Park 2015). Confronted with narrower bid-ask spreads, some traditional market makers have allocated fewer resources to market making or have withdrawn from the business entirely. As a result, HFT now supplies the majority of liquidity in about half of all TSX Venture securities. To be clear, however, HFT differs from traditional market making in that such market makers have no obligation - to their clients or to exchanges - to supply liquidity to the market; in fact, any liquidity HFT firms provide is merely a byproduct of their trading.

The conditions described above might explain the reluctance to date to establish a market-maker

12 This feature distinguishes TSX Venture from most European markets for SMEs, where IPOs are offered exclusively to institutional investors and, as a result, generally fail to develop liquid trading (Vismara, Paleari, and Ritter 2012).

13 Currently, TSX Venture rules require tick sizes of one cent for securities sold above $\$ 0.50$ and half a cent for securities sold below that price. 
system on TSX Venture. ${ }^{14}$ HFT is not a solution: its participation in TSX Venture securities is much lower than that for TSX securities. On TSX Venture, HFT occurs in only about half of all listed securities, accounting for about 20 percent of all transactions and less than 10 percent of the trading value (Malinova and Park 2015). The absence of a market-maker system for TSX Venture securities is not inconsequential for the quality of the TSX Venture market. A recent study of trading activity reveals that:

- on any given trading day, only half of the listed issuers are traded;

- nearly 7 percent of the listed issuers eligible for trading in a given month do not trade on any day of the month; and

- a significant number of listed issuers are traded or traded at closing at a price of $\$ 0.10$ or less (IIROC 2014).

Small capitalized companies thus face unfavourable market dynamics, which is a key challenge for TSX Venture in terms not only of market quality, but also of their lingering negative effects on TSX Venture's reputation with entrepreneurs, financial intermediaries and investors. The continued success of TSX Venture thus hinges on three major conditions: (i) the active and prevalent participation of retail investors; (ii) the liquidity of TSX Venturelisted securities; and (iii) a neutral fiscal stance with respect to similar public and private high-growth companies:

- Retail investor participation: The consolidation of the securities industry within the banking and insurance sectors, the shift from transactional to wealth advisory and asset management services and regulatory changes are contributing factors to the reduction of liquidity. Large financial institutions have a pronounced aversion to reputational risk, which makes them shy away from recommending early-stage public companies and small-cap securities to retail clients, a cautionary note that is easier to justify in the context of uncertainties surrounding the interpretation by the brokerage industry of the Investment Industry Regulatory Organization of Canada's suitability rules and Client Relation Model.

- Market liquidity: Historically, independent TSX Venture dealer members have been the primary providers of liquidity and the primary distribution channel for new equity issues by TSX Venture companies. The decline of these independent dealers deprives the exchange of one of its main strengths. TMX Group has committed to establishing a market-making program on TSX Venture as part of its plan to revitalize the exchange (TMX 2015), but so far no market makers have been appointed for TSX Venture securities. ${ }^{15}$

- Equity research: Equity research fulfills a critical function in equity markets. It is of particular importance in the case of small innovative and high-growth companies for which reliable information is scarcse and difficult to assess.

- The taxation regime: High-growth and innovative Canadian companies lose most of the benefits of the federal SR\&ED credits program when they go public, but not if they are privately financed. This bias of federal fiscal policy is counterproductive. Canadian public companies should be eligible for the SR\&ED program in the same way as Canadian-controlled private corporations of comparable size and stage of development.

14 TSX Venture has implemented an Odd Lot Dealer system, whereby dealers are required to provide an automatic immediate fill for incoming tradable odd lots at the best-posted price on the exchange. Odd lots resting in the book, which later become tradable due to a change in the best-posted price, are also automatically filled by the Odd Lot Dealer. This function does not include the key responsibilities assigned to specialists and market makers.

15 In the United States, companies that list their shares on NASDAQ's BX Venture Market are required to have at least two market makers. 
PUBLIC VERSUS PRIVATE CANAdian EQUITY CAPITAL MARKETS

A substantial body of academic literature documents the additional role that private equity and venture capital firms play in financing entrepreneurial companies. In addition to capital, these professional investors bring specialized skills, financial management expertise, operational experience and technical and market knowledge that are deployed to mentor and help entrepreneurs and executives avoid costly errors and focus on key success factors. ${ }^{16}$ Recent empirical studies show that, indeed, these investment firms add real value: for example, the average performance of Canadian firms that received venture capital financing is significantly superior to that of comparable nonventure-capital-backed firms on key metrics: (i) stronger revenue growth; (ii) sales growth; (iii) headcount growth; (iv) asset growth and $\mathrm{R} \& \mathrm{D}$ expenditure growth (Industry Canada and CVCA 2013). These findings are similar to those obtained in an analysis of the performance of venturecapital- and non-venture-capital-financed firms in the United States (Puri and Zarutskie 2012). The conclusion to be drawn from these studies is that venture-capital-financed firms change significantly compared to non-venture-capital-financed firms in terms of growth rates and size after venture capital firms become involved.

Although they take great care to ensure a meaningful match between venture-capital-backed firms and non-venture capital-backed firms on key financial metrics, these econometric analyses do not take into account the idiosyncracies and motivations of the entrepreneurs at the helm of SMEs. The proportion of SMEs that have received private capital is very small - less than 1 percent. ${ }^{17}$ It is well documented that a large proportion of SME owners state that they do not have high growth aspirations (Hurst and Pugsley 2011). Nor do the studies compare the performance of similar companies that have chosen private versus public venture capital. Such a comparison is important. Several large international bodies, including the World Bank and the European Commission, argue that capital markets play a critical role through the provision of alternative funding sources for high-growth and innovative firms, and recommend fostering the development of junior markets to serve as a stepping stone to a main stock exchange, where more funding and liquidity are available (European Commission 2015; IMF 2015; Nassr and Wehinger 2015).

It is instructive that the importance of private capital to economic growth has been shown to be true across a number of different countries and to occur across a broad spectrum of critical areas, including innovation, productivity and competitiveness. For example, Popov and Rosenboom (2009) find that, in the European Union, private capital accounts for only 8 percent of industrial spending but 12 percent of industrial innovation. Similarly, Samila and Sorenson (2011), in their US study, find impressive knock-on effects from private capital, as each private-equity-backed

16 These considerations are some of the main points put forward by Innovation, Science and Economic Development Canada (see Canada 2017).

17 In the United States, by far the largest market for venture capital in the world, the National Venture Capital Association reports that an average of fewer than 1,200 firms received venture capital for the first year, or approximately 0.2 percent of the firms that are started each year (Kaplan and Lerner 2017). Puri and Zarutskie (2012) report similar results. During the 1996 to 2000 period, only 0.22 percent of all the new firms created got VC backing. In Canada, the total number of SMEs with employees is about 1.17 million, and the annual creation of new firms with employees averages 96,000 (Canada 2018). The average number of venture capital and private equity investments per annum in recent years has been 468 and 391, respectively - less than 0.1 percent of the SME population. 


\section{Figure 6: Impulse Response Functions, Private Capital Shock (Percent)}

GDP

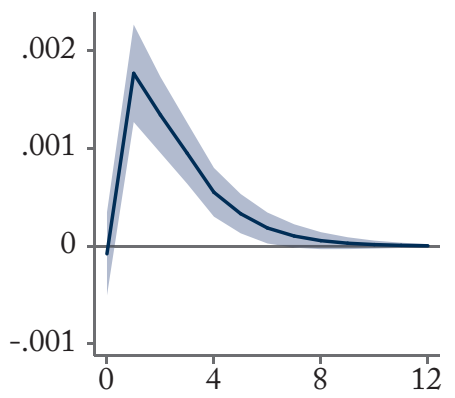

Employment

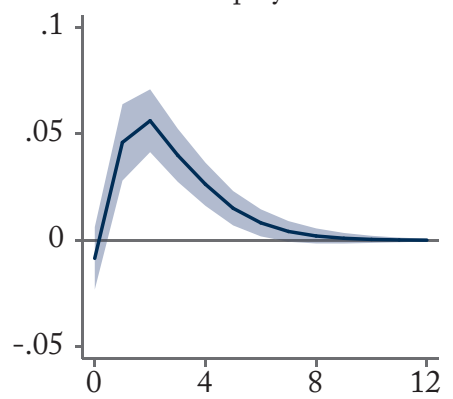

$\mathrm{R} \& \mathrm{D}$

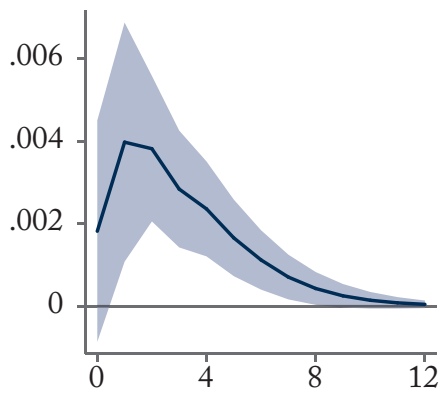

Net Exports

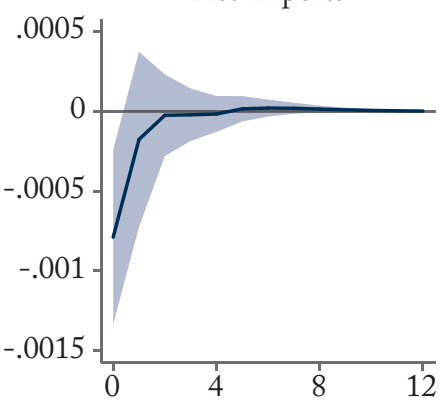

Business Investment

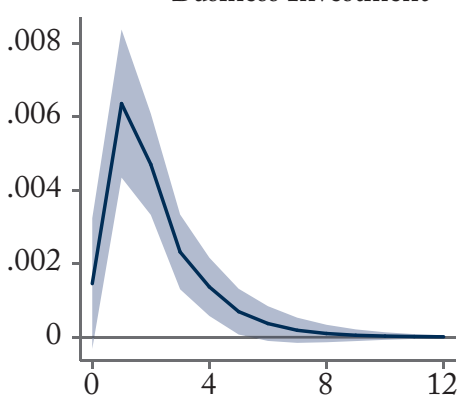

Note: Each of the variables is non-stationary in levels, and are thus differenced. There is no co-integration amongst the variables so the SVAR may be run in growth rates without the use of an error correction term.

Source: Statistics Canada.

firm leads to the creation of a further 10 companies.

These results give strong credence to the view that both public and private capital markets play a complementary role in the Canadian economy. This proposition can be tested quantitatively, using a structural vector autoregression (SVAR), to see whether a positive shock to the market value of either private or public equity capital shares leads to a positive response in a series of macroeconomic variables, including real GDP, the employment rate, business fixed capital formation, $R \& D$ (proxied for with intellectual property products) and net exports, all using data from Statistics Canada (see Figures 6 and 7). For private and public capital markets, the analysis makes use of Statistics Canada's National Balance sheet accounts, which include data for both listed (public) and unlisted (private) shares, with a focus on the stocks of each, at market value. The private or public capital stock growth is ordered as the first variable in the analysis. By placing these variables first, the implicit assumption is that the equity capital markets represent a leading indicator for the health of the economy. This assumption is based on Statistics Canada's Composite Leading 


\section{Figure 7: Impulse Response Functions, Public Equity Shock (Percent)}
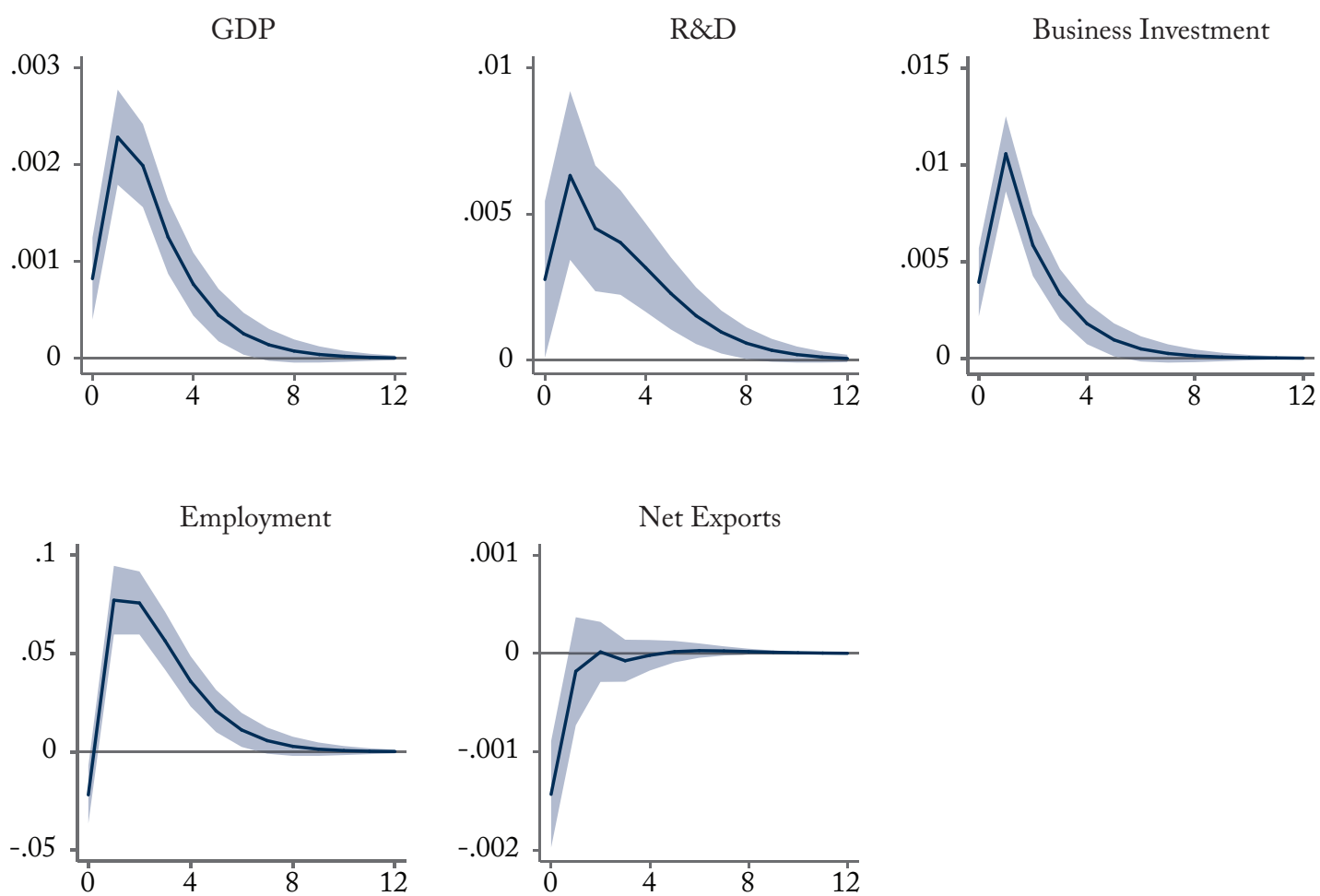

Note: Each of the variables is non-stationary in levels, and are thus differenced. There is no co-integration amongst the variables so the SVAR may be run in growth rates without the use of an error correction term.

Source: Statistics Canada.

Indicator index, ${ }^{18}$ published monthly since February 1981, which includes the stock market as one of ten components. ${ }^{19}$

Figure 6 shows the effect of a positive shock to the growth of the stock of private capital on the aforementioned set of macroeconomic variables. Note that the overall economy responds with a peak increase to its growth rate of 18 basis points. This is driven by increases in the growth of $R \& D$ and business investment, with growth in the employment rate positively affected as well although, given the use of growth rates, these are short-run effects. Interestingly, net export growth is negatively affected, but this is driven by increases in both export and import growth, with the latter growing faster than the former. Increases in both are a sign of a strong economy. ${ }^{20}$

Figure 7 repeats the same exercise for the growth of the stock of public (equity) capital, where the results reveal very similar responses to the

18 See Statistics Canada, "Canadian Composite Leading Indicator (CI)," available online at http://www23.statcan.gc.ca/imdb/ p2SV.pl?Function=getSurvey\&SDDS=1601.

19 This assumption is also consistent with Aldatmaz and Brown (2018).

20 Impulse responses for exports are available from the author upon request. 
macroeconomic variables from a positive shock. For example, the GDP growth rate now increases by 23 basis points. Readers should not get bogged down in the magnitude per se, however, as the size of the shock is based on one unit variance, and volatility is higher in the case of public equity capital. And, in any event, given the specific circumstances each company faces when making the decision whether to go private or public, the more important result is the positive response of the macro variables to a positive shock to each form of equity capital. Indeed, as Aldatmaz and Brown (2018) show, there might even be benefits to public firms from an increase in private investments.

\section{EXIT PATHS ARE NOT NEUTRAL}

The gradual slowdown in the rate of productivity growth in industrial economies in recent decades and the negative pressure that aging populations will exert on it in the future have drawn attention to the fact that high-growth firms are a key lever in improving productivity and wealth creation. Scaling up SMEs has become a policy priority to address low productivity growth in OECD countries. It is unlikely that Canada will improve its low ranking in innovation and productivity growth among its OECD peers - despite the positive results above arising from public and private equity capital market investment - if it fails to develop more Canadian multinationals around which new technology companies can emerge and grow in symbiosis.

The productivity level of companies is a function of their size (Leung, Meh, and Terajima. 2018). This positive correlation applies to all sectors. In Canada, it has been observed that companies with more than 500 employees and those with 100 to 500 employees have productivity levels that are 30 percent and 20 percent higher, respectively, than those of companies with fewer than 100 employees. This productivity gap also increases over time, because productivity gains depend on the assimilation of expertise, competencies and best practices within companies and from their continuous adaptation. This process takes time. Think of the learning curve: advances in productivity are a function of cumulative output, not cumulative investment. Moreover, productivity differences between exchange-listed companies of different sizes are much less pronounced, a strong indication that a stronger capital structure leads to higher productivity, since it facilitates increases in capital intensity (Lee and Tang 2001).

Since private equity and venture capital firms seek to invest in firms that have the potential to grow into sizable companies with the resources necessary to compete in world markets, how and when they disinvest their portfolio is an important policy issue. The Canadian public venture capital market provides a "real life" case for empirical analysis of the trajectory of growth-oriented SMEs, depending on whether they have chosen the private or the public market financing option. Comparing non-resources-based companies graduating from TSX Venture to the TSX to benchmark firms that listed on the TSX pursuant to an IPO, Carpentier and Suret (2018) find that TSX Venture nurtures small, dynamic firms - the earnings of future graduates grow about twice as fast each year (57 percent) as those of the benchmark firms (32 percent); and the probability of reaching the TSX is much higher for TSX Venture companies than for venture-capital-backed firms 15.9 percent versus less than 3 percent.

In Canada, private equity and venture capital firms, including government agencies and sponsored funds, prefer trade sales (78 percent) over an IPO (13 percent) as the exit path. A factor that seems to influence the stronger propensity for trade sales versus IPOs in Canada than in the United States is that the size of private equity and venture capital investments in Canada is significantly smaller than in the United States or the United Kingdom. Since 2012, normalized for their respective GDP, the frequency of private equity capital financings greater than $\$ 50$ million was six times higher in 
the United States and three times more frequent in the United Kingdom than in Canada (TMX 2017). In 2017, the average investment amount by Canadian venture capital firms was $\$ 8.04$ million, compared with $\$ 25.9$ million in California and $\$ 22.8$ million in Massachusetts. The situation is particularly worrisome for later-stage financings, where Canadian companies raise less than onequarter the amount comparable US companies do (TMX 2017).

Foreign trade sales by venture capital firms are common and increasing. This pattern is consistent with cross-country observations that the number of trade sales is considerably larger than the number of IPOs and that, for OECD members, "the fact that a start-up received government venture capital support instead of only private venture capital funding does not impact the probability of acquisition or IPO" (Breschi, Lassébie, and Menon 2018). Over the 2001-12 period, 57 percent of trade sales were done with foreign firms, and in Canada this generally means that these knowledge-based companies will be acquired by and subsumed within foreign companies based mainly in the United States. This generally results in the relocation, or "migration," of $\mathrm{R} \& \mathrm{D}$ and executive decision-making functions or of the entire business outside Canada (Carpentier and Suret 2014b). Even if such transactions arise from strategic considerations, the fact remains that company ownership has a considerable influence on the strategies pursued, the location of critical functions, including $\mathrm{R} \& \mathrm{D}$, and integration into the fabric of its business and societal environment roles that truncated companies with hollowed-out capabilities do not fulfill.

In this regard, we need to take into account that, in addition to tax incentives for R\&D spending, 15 OECD countries grant preferential tax treatment for revenues generated by the commercialization of intellectual property, including patents, copyrights and process designs for which they have incurred expenditures such as R\&D costs. This is not the case in Canada either at the federal level or in most provinces. Although there is scant evidence that such an income-based tax measure fuels greater R\&D activities, it has a strong effect on patent location (Alstadsaeter et al. 2015), and influences that of marketing and sales activities (Lester and Warda 2018).

The point here is not that foreign-owned companies with operations in Canada do not promote productivity growth and do not make a valued contribution to the Canadian economy. The issue is that the trade sales generally involve the acquisition of new, technology-based firms that have not yet reached business maturity by multinational companies of a size that dwarfs the Canadian company being acquired. In these circumstances, hollowing of the acquired firm is the rule, not an exception.

There is no denying that several crucial considerations determine the choice of exit path by private equity and venture capital firms. The strength of competition in product markets is a crucial factor: will the firm be able to fend for itself and grow independently after going public, or is it more valuable to an acquirer able to benefit from the synergies resulting from the integration of the targeted company into its activities? This, in turn, depends on the value attributed to the firm at the time of the IPO, the determination of the entrepreneur-shareholder to remain, or not, in control of his or her destiny and the expectations regarding the evolution of the share price thereafter (Bayar and Chemmanur 2012). The latter point is a particularly important consideration for the private investors because securities and stock exchange regulations require that they, and the senior executives of the company, place the shares and convertible securities they retain in escrow which can only be released in tranches that extend to 18 months after the listing date (OSC).

The example of BRP illustrates the points above. The company was privatized with the participation of Beaudier inc, Bain Capital and the Caisse de dépôt et placement du Québec; it subsequently 
went public and is listed on the TSX. Today, this Québec-based company is the undisputed world leader in the design, manufacturing, distribution and marketing of motorized recreational products. What would remain of the main engineering, technical and business functions in Canada if, rather than follow the course it did, the company had been acquired by Honda, Kawasaki, Polaris, Suzuki or Yamaha when it was spun off by Bombardier?

More generally, the role of private equity is to make businesses grow once they are past the venture stage. This in turn helps strengthen Canada's economy along a number of dimensions of success, as illustrated in Figure 7.

\section{CONCLUSION}

Private capital plays an important and growing role in connecting financial resources to investment opportunities in a highly productive manner. Governments that have spent considerable resources supporting investments in the venture stage of Canadian firms' growth need also to pay attention to the next stages. Exchange-listed companies, IPOs, venture capital and private equity are all complementary investment avenues. Each plays a vital role that allows companies more efficient access to capital for improving productivity, boosting long-term growth and innovation, and creating better jobs.

Despite positive trends in the volume and sources of private capital in recent years, Canada continues to face persistent challenges: the median size of exits is almost an order of magnitude smaller than in the United States (BDC 2017), and institutional equity investors systematically engage in trade sales rather than IPOs.
This creates a conundrum. On the one hand, the vitality of private capital markets depends on investment returns achieved by private equity and venture capital firms: hence the search for the most lucrative and less burdensome exit. On the other hand, the sale of new technology-based and highgrowth companies to foreign firms generally leads to the migration of innovation and productive capacity outside Canada's borders.

One powerful disincentive to exit through public markets is federal government tax policies that discriminate against and penalize Canadian innovative and high-growth companies that "go public" (Chen and Mintz 2011). In addition to correcting these counterproductive biases, serious consideration should be given to adopting a tax measure similar to the US Small Business Jobs Act of 2010, which provides for full exemption from federal taxation of capital gains realized on the sale of the shares of certain small businesses. There is empirical evidence that the exemption increased "the amount of investment in start-up firms and the number of investors per funding round by about 12 percent" (Edwards and Todtenhaupt 2018, p.33).

Serious consideration should also be given to reducing the capital gains tax on shares issued by qualified SMEs when they list on a Canadian stock exchange and are held by individual investors for a reasonable period of time, since evidence suggests that capital gains taxes influence the underpricing of IPOs (Li, Lin, and Robinson 2016). The adoption of such a tax measure applicable to exits by an IPO or upon listing the shares on a Canadian stock exchange would help establish a more neutral playground for the choice of exits, which, to a large extent, is the crux of the matter. 


\section{APPENDIX A: REPRESENTATIVE EXAMPLES OF PRIVATE EQUITY CAPITAL SUPPORTING GROWTH OF CANADIAN-BASED COMPANIES}

\begin{tabular}{|c|c|c|c|}
\hline$\$ 1$ Billion or more & $\begin{array}{l}\text { LifeLabs acquires } \\
\text { CML HealthCare } \\
\text { Inc. }\end{array}$ & 1 & $\begin{array}{l}\text { LifeLabs Medical Laboratory Services, a Canadian medical diagnostic services } \\
\text { provider owned by the Ontario Municipal Employees Retirement System, } \\
\text { acquired Mississauga-based rival CML Healthcare Inc., whose main shareholder } \\
\text { was Boston-based Fidelity Investments, in 2013. This made the LifeLabs, } \\
\text { headquartered in Toronto, the fourth-largest medical testing lab company in the } \\
\text { world, dominant for non-hospital tests in Ontario and British Columbia, and } \\
\text { better able through efficiencies enabled by the merger to face constant pressures by } \\
\text { provincial governments to cut costs and invest in new technologies. LifeLabs has } \\
\text { subsequently expanded both geographically and in terms of service offerings. }\end{array}$ \\
\hline $\begin{array}{l}\text { \$500 Million to } \\
\text { \$1 Billion }\end{array}$ & $\begin{array}{l}\text { CDPQ \& Novacap } \\
\text { invest in Pivotal } \\
\text { Payments }\end{array}$ & 1 & $\begin{array}{l}\text { Novacap and Caisse de dépôt et placement du Québec invested in Pivotal } \\
\text { Payments in 2017, a Québec business providing payment processing solutions and } \\
\text { services. This investment is part of Pivotal's "aggressive growth plan" to acquire new } \\
\text { payment and fintech solutions and expand into new markets, such as the United } \\
\text { States (where it operates an IT and development center in Plano, Texas), as well as } \\
\text { Australia and New Zealand, while keeping the company headquartered in Canada. } \\
\text { Since then, the company has announced that it will rebrand and operate under the } \\
\text { new name Nuvei, and create a community of payment experts, the first of its kind. }\end{array}$ \\
\hline \multirow{2}{*}{$\begin{array}{l}\text { \$100 Million to } \\
\$ 500 \text { Million }\end{array}$} & $\begin{array}{l}\text { NOVACAP } \\
\text { Industries IV and } \\
\text { LP partners invest } \\
\$ 165 \mathrm{M} \text { in } \mathrm{KDC}\end{array}$ & & $\begin{array}{l}\text { In 2014, Novacap partnered with its NOVACAP Industries IV investment fund, } \\
\text { and other institutional players, including Caisse de dépôt et placement du Québec, } \\
\text { investing more than } \$ 165 \text { million in KDC, a leading contract manufacturer of } \\
\text { health and beauty-care products. Novacap, through its NOVACAP II Fund, } \\
\text { first invested in KDC, formerly a division of US-based Clairol, in } 2002 \text {. Over } \\
\text { this } 2002-2018 \text {, NOVACAP and its partners invested in KDC to increase its } \\
\text { North American footprint in vertically integrated manufacturing of health and } \\
\text { beauty-care products, expanding sales more than twenty-fold while remaining } \\
\text { headquartered in Québec. It was sold to New-York based investors in } 2018 \text {. }\end{array}$ \\
\hline & $\begin{array}{l}\text { Agropur closes } \\
\text { growth capital } \\
\text { financing }\end{array}$ & 2 & $\begin{array}{l}\text { In 2015, Québec's institutional investors, La Caisse de dépôt et placement du } \\
\text { Québec, National Bank, the Fonds de solidarité FTQ, Investissement Québec, } \\
\text { and Capital régional et coopératif Desjardins and Fondaction CSN, invested in } \\
\text { Agropur Cooperative to further its growth in the North American dairy industry. } \\
\text { This group had already invested in Agropur in 2014. These investments are aimed } \\
\text { to support acquisitions of New Brunswick's Northumberland Dairy Co-operative, } \\
\text { United States-based Davisco Foods International, Inc., and the Western Canadian } \\
\text { milk, yogurt and ice cream manufacturing operations of Sobeys Inc., which will } \\
\text { rank Agropur among the largest North American dairy product processors. At the } \\
\text { time of the transaction, Agropur had 6,500 employees in Canada and the United } \\
\text { States and } 32 \text { plants across North America. Today it has over } 8,800 \text { employees and } \\
39 \text { processing and distribution facilities across North America. }\end{array}$ \\
\hline
\end{tabular}




\begin{tabular}{|c|c|c|c|}
\hline \multirow{3}{*}{$\$ 100$ Million or less } & $\begin{array}{l}\text { Mosaic Capital } \\
\text { acquires Mackow } \\
\text { Industries }\end{array}$ & 2 & $\begin{array}{l}\text { Mosaic, a Canadian investment company focused on established mid-sized niche } \\
\text { businesses, acquired a majority stake in Mackow Industries, a Winnipeg-based } \\
\text { family-owned metal fabrication company. Mosaic acquired } 80 \% \text { equity interest in } \\
\text { Mackow in 2016, giving it the needed support to expand operations into a second } \\
\text { facility in Fargo, North Dakota. Mackow estimated that around } 12 \text { employees will } \\
\text { be hired from the Fargo area, with no one being moved from Winnipeg. The new } \\
\text { plant has a plant manager to run operations there, and the Winnipeg management } \\
\text { will go back and forth. This acquisition helped Mackow grow internationally while } \\
\text { maintaining its ownership within the family. }\end{array}$ \\
\hline & & & \\
\hline & $\begin{array}{l}\text { BluEarth } \\
\text { Renewables } \\
\text { closes } \$ 81 \mathrm{M} \text { new } \\
\text { financing }\end{array}$ & 1 & $\begin{array}{l}\text { In November 2014, Ontario Teachers' Pension Plan (Teachers') and ARC } \\
\text { Financial, along with other investors, injected a new round of equity financing ( } \$ 81 \\
\text { million) into BluEarth Renewables Inc, a company focused on commercial scale } \\
\text { renewable energy developments. At the time of investment, BluEarth had raised } \\
\text { over } \$ 250 \text { million in equity. The goal of the new round of financing was to support } \\
\text { BluEarth's continued growth and investment in projects related to renewable } \\
\text { energy, which has occurred with the development or acquisition of a number of } \\
\text { wind, solar and hydroelectric projects across Ontario and Western Canada. Since } \\
\text { then, it has opened new headquarters in Calgary, and has entered the US market. }\end{array}$ \\
\hline
\end{tabular}




\section{REFERENCES}

Aldatmaz, Serdar, and Gregory W. Brown. 2018. "Private Equity in the Global Economy: Evidence on Industry Spillovers." UNC Kenan-Flagler Research Paper 2013-9. http://dx.doi.org/10.2139/ ssrn. 2189707

Alstadsaeter, Annette, Salvador Barrios, Gaétan Nicodème, Agnieszka Maria Skonieczna, and Antonio Vezzani. 2015. "Patent Boxes Design, Patents, Location and Local R\&D.” Oxford: Oxford University, Centre for Business Taxation.

Bainbridge, Stephen M. 2010. "Corporate Governance and U.S. Capital Market Competitiveness.” Social Science Research Network. October. Available online at https://papers.ssrn.com/sol3/papers. cfm?abstract_id=1696303

Bank of Canada. 2018. Minerals and Metal Price Index. Ottawa.

Bayar, Onur, and Thomas Chemmanur. 2012. "IPOs versus Acquisitions and the Valuation Premium Puzzle: A Theory of Exit Choice by Entrepreneurs and Venture Capitalists." Journal of Financial and Quantitative Analysis 46 (6): 1755-93.

BDC. 2017. "Canada's Venture Capital Landscape: Challenges and Opportunities." June.

Boadway, Robin, and Jean-François Tremblay. 2017. "Policy Forum: The Uneasy Case for a Canadian Patent Box." Canadian Tax Journal 65 (1): 61-72.

Breschi, Stefano, Julie Lassébie, and Carlo Menon. 2018. "A Portrait of Innovative Start-Ups across Countries." OECD Science, Technology and Industry Working Paper 2018/02. Paris: Organisation for Economic Co-operation and Development.

Canada. 2017. Innovation, Science and Economic Development Canada. "Designing the Venture Capital Catalyst Initiative.” Discussion Paper. Ottawa. Available online at https://www.ic.gc.ca/eic/ site/061.nsf/vwapj/VCCI_discussion_paper_2017eng.pdf/\$file/VCCI_discussion_paper_2017-eng. pdf.
2018. Industry Canada. "Canadian New Firms: Birth and Survival Rates over the Period 20022014." Ottawa. May. Available online at https:// www.ic.gc.ca/eic/site/061.nsf/vwapj/CNF_BSRNEC_TNS_2002-2014_May2018_eng.pdf/\$file/ CNF_BSR-NEC_TNS_2002-2014_May2018_eng. pdf.

Carpentier, Cécile, and Jean-Marc Suret. 2014a. "Post-Investment Migration of Canadian Venture Capital-Backed New Technology-Based Firms." CIRANO Working Paper 2014s-27. Montreal: Centre interuniversitaire de recherche en analyse des organisations.

_ 2014b. "Post-Investment Migration of Québec Venture-Capital-Backed New Technology-Based Firms." Canadian Journal of Regional Science 37 (13): 71-80.

. 2018. "Entrepreneurs and Junior Markets: An Assessment.” CIRANO Working Paper 2018s-18. Montreal: Centre interuniversitaire de recherche en analyse des organisations.

Carpentier, C., Jean-François L'Her, Jean-Marc Suret, Stock Exchange Markets for New Ventures, CIRANO, April 2008.

CCA (Council of Canadian Academies) 2018. Competing in a Global Innovation Economy: The Current State of REDD in Canada. Ottawa. April.

Chen, Duanjie, and Jack Mintz. 2011. "Small Business Taxation: Revamping Incentives to Encourage Growth." Calgary: University of Calgary, School of Public Policy.

Chin, Faith, and Corey Garriott. 2016. "Options Decimalization.” Staff Working Paper 2016-57. Ottawa: bank of Canada.

Committee on Capital Markets Regulation. 2006. Interim Report of the Committee on Capital Markets Regulation. Washington, DC. November 30.

Cournède, Boris, and Oliver Denk. 2015. "Finance and Economic Growth in OECD and G20 Countries." Working Paper 1223. Paris: Organisation for Economic Co-operation and Development. June. 
CVCA (Canadian Venture Capital, and Private Equity Association). 2018. "VC \& PE Canadian Market Overview//H1 2018.”

de Fontenay, Elisabeth, The Deregulation of Private Capital and the Decline of the Public Company, 68 HASTINGS I., J. 445, 2017.

Doidge, Craig, G. Andrew Karolyi, and René M. Stulz. 2015. “The U.S. Listing Gap.” NBER Working Paper 21181. Cambridge, MA: National Bureau of Economic Research. May.

Economist, American start-ups bave less need to list on the stock market, September 29th, 2018.

Edwards, Alexander, and Maximilian Todtenhaupt. 2018. "Capital Gains Taxation and Funding for Start-Ups.” ZEW Discussion Paper 18-046. Mannheim: ZEW-Leibniz Centre for European Economic Research, Available online at http://ftp. zew.de/pub/zew-docs/dp/dp18046.pdf.

European Commission. 2015. Capital Markets Union: An Action Plan to Boost Business Funding and Investment Financing. Brussels: European Commission. September.

Guetierrez, German, and Thomas Philippon 2018. "How EU Markets Became More Competitive Than U.S. Markets: A Study of Institutional Drift," NBER Working Paper no. 24700, June.

Hurst, Erik, and Benjamin Wild Pugsley. 2011. "What Do Small Business Do?” Brookings Paper on Economic Activity 2: 73-142.

Industry Canada and CVCA. 2013. The Performance of Canadian Firms that Received Venture Capital Financing. Ottawa. June.

IMF (International Monetary Fund). 2014. IOSCO Objectives and Principles of Securities RegulationDetailed Assessment of Implementation. Washington, DC: IMF. March.

IIROC (Investment Industry Regulatory Organization of Canada). 2014. "Selected Background Information for the IIROC Venture Market Roundtable." Notice 14-0117. Toronto. May. Available online at http://www.iiroc.ca/ Documents/2014/6bfd4210-050a-4ff2-9e73491421c7cc03_en.pdf.
IOSCO, SME Financing through Capital Markets, The International Organization of Securities Commission, 2015.

Kaplan, Steven N., and Josh Lerner. 2017. "Venture Capital Data: Opportunities and Challenges.” Harvard Business School Working Paper 17-012. Cambridge, MA: Harvard Business School.

Leduc, Sylvain. 2017. "Seeking Gazelles in Polar Bear Country." Remarks to the Sherbrooke Chamber of Commerce, October 3. Available online at https:// www.bankofcanada.ca/2017/10/seeking-gazelles-inpolar-bear-country/.

Lee, Kyle, and Konstantin Synetos. 2018. "The Emergence of Long-Term Capital in Private Equity." INSEAD. June. Available online at https:// www.insead.edu/sites/default/files/assets/dept/ centres/gpei/docs/insead-isp-the-emergence-oflong-term-capital-in-private-equity-jun-2018.pdf.

Lee, Frank, and Jianmin Tang. 2001. "Multifactor Productivity Disparity between Canadian and U.S. Manufacturing Firms." Journal of Productivity Analysis 15 (2): 115-28.

Lester, John, and Jacek Warda. 2018. "An International Comparison of Tax Assistance for R\&D: 2017 Update and Extension to Patent Boxes." Calgary: University of Calgary, School of Public Policy.

Leung, Danny, Césaire Meh, and Yaz Terajima. 2008. "Productivity in Canada: Does Firm Size Matter?" Bank of Canada Review (Autumn): 5-14.

Li, Oliver Zhen, Yupeng Lin, and John R. Robinson. 2016. "The Effect of Capital Gains Taxes on the Initial Pricing and Underpricing of IPOs." Journal of Accounting and Economics 61 (2-3): 465-85.

Lortie, Pierre. 2010. "Securities Regulation in Canada at a Crossroads.” Calgary: University of Calgary, School of Public Policy. October.

Lowry, Michelle, Roni Michaely, and Ekaterina Volkova. 2017. Initial Public Offerings: A Synthesis of the Literature and Directions for Future Research. Foundations and Trends in Finance. August. 
Malinova, Katya, and Andreas Park. 2015. "Liquidity Provision and Market Making by HFTs.” Toronto: Investment Industry Regulatory Organization of Canada. September.

Melo, Patricia C., Daniel J. Graham, David Levinson, and Sarah Aarabi. 2016. "Agglomeration, Accessibility and Productivity: Evidence for Large Metropolitan Areas in the US." Urban Studies Journal 54 (1): 179-95.

Meluzin, Tomas, Marek Zinecker, Trends in IPOs: The evidence from CEE capital markets, Equilibrium, Quarterly Journal of Economics and Economic Policy, Vol. 11, No. 2, 2016.

Merrill, Peter, "Innovation Boxes: BEPS and Beyond." National Tax Journal, 69(4), 2016.

Nassr, Iota Kaousar, and Gert Wehinger. 2015. "Opportunities and Limitations of Public Equity Markets for SMEs." OECD Journal: Financial Market Trends 3 (1): 1-36.

Natural Resources Canada, "Canadian Mineral Exploration.” Information Bulletin, Ottawa, March 2018.

OECD (Organisation for Economic Co-operation and Devlopment). 2003. The Sources of Economic Growth in OECD Countries. Paris: OECD.

- 2017. Entrepreneurship at a Glance. Paris: OECD Publishing.

OSC (Ontario Securities Commission), National Policy 46-201, "Escrow for Initial Public Offerings." Available at http://www.osc.gov.on.ca/documents/ en/Securities-Category4/pol_20020628_46-201.pdf

Peterhoff, Daniela, John Romeo, and Paul Calvey. 2014. "Towards Better Capital Market Solutions for SME Financing." Oliver Wyman. Available online at https://www.oliverwyman.com/ content/dam/oliver-wyman/global/en/files/ insights/financial-services/2014/July/FINAL3_ BetterCapitalMarketMechanismsSMEs.pdf.

Popov, Alexander, and Peter Roosenboom. 2009. "Does Private Equity Investment Spur Innovation? Evidence from Europe.”Working Paper 1063. Frankfurt-am-Main: European Central Bank. June.
Puri, Manju, and Rebecca Zarutskie. 2012. "On the Life Cycle Dynamics of Venture-Capital- and NonVenture-Capital-Financed Firms." Journal of Finance 67 (6): 2247-93.

PwC and FMC Law. 2012. "Toward More Democratic Corporate Financing." Available online at https:// www.slideshare.net/fmclaw/toward-moredemocratic-corporate-financing.

Rémillard, Richard. 2017. Government Intervention in Venture Capital in Canada: Toward Greater Transparency and Accountability. Commentary 466. Toronto: C.D. Howe Institute.

Robson, William B.P., Jeremy Kronick, and Jacob Kim. 2018. Tooling Up: Canada Needs More Robust Capital Investment. Commentary 520. Toronto: C.D. Howe Institute.

Romano, Roberta. 2005. "Quack Corporate Governance.” Regulation 28 (4): 36-44

Samila, Sampsa, and Olav Sorenson. 2011. "Venture Capital, Entrepreneurship and Economic Growth." Review of Economics and Statistics 93 (1): 338-49.

Schwab, Klaus, ed. 2018. The Global Competitiveness Report 2018. Geneva: World Economic Forum.

Sorenson, Olav, and Toby E. Stuart. 2001. "Syndication Networks and the Spatial Distribution of Venture Capital Investments." American Journal of Sociology 106 (6): 1546-88.

Stewart, Luke A., and Robert D. Atkinson. 2013. "Restoring America's Lagging Investment in Capital Goods."Washington, DC: Information Technology and Innovation Foundation. October.

Tingle, Bryce, J. Ari Pandes, and Michael J. Robinson. 2013. "The IPO Market in Canada: What a Comparison with the United States Tells Us about a Global Problem." Canadian Business Law Journal 54 (3): 321-68.

TMX. 2015. "Revitalizing TSX Venture Exchange.” Toronto. December.

. 2017. "Unlocking Growth Opportunities for Canada's Innovation Economy.”Toronto. 
Vismara, Silvio, Stefano Paleari, and Jay R. Ritter. 2012. "Europe's Second Markets for Small Companies." European Financial Management 18 (3): 352-88.

World Bank. 2018. World Bank Indicators: Stock Markets. Washington, DC.

Zinecker, Marek, Tomas Meluzin, Private Equity and Venture Capital: an Empirical Analysis, Equilibrium, Quarterly Journal of Economics and Economic Policy, Vol. 6, No. 2, 2011. 


\section{ReCEnt C.D. Howe Institute Publications}

February 2019 Blomqvist, Åke, and Rosalie Wyonch. "High Drug Prices, Big R\&D Spenders and "Free Riders": Canada in the Topsy Turvy World of Pharmaceuticals.” C.D. Howe Institute Commentary 535.

February 2019 Bishop, Grant, and Grant Sprague. "A Crisis of Our Own Making: Prospects for Major Natural Resource Projects in Canada.” C.D. Howe Institute Commentary 534.

February 2019 Naugler, Christopher, and Rosalie Wyonch. "What the Doctor Ordered: Improving the Use and Value of Laboratory Testing." C.D. Howe Institute Commentary 533.

février 2019 Wyonch, Rosalie, et Abby Sullivan. "Santé et bonne scolarité : Les programmes d'alimentation saine au Canada" Institut C.D. Howe commentaire $\mathrm{N}^{\circ} 532$.

February 2019 Wyonch, Rosalie, and Abby Sullivan. "Health and Grades: Nutrition Programs for Kids in Canada.” C.D. Howe Institute Commentary 532.

February 2019 Robson, William B.P., and Alexandre Laurin. "Less Debt, More Growth: A Shadow Federal Budget for 2019.” C.D. Howe Institute Commentary 531.

January 2019 Landon, Stuart, and Constance Smith. "Managing Uncertainty: The Search for a Golden Discount-Rate Rule for Defined-Benefit Pensions” C.D. Howe Institute Commentary 530.

janvier 2019 Mahboubi, Parisa. "L'équité intergénérationnelle : Nos enfants auront-ils une meilleure vie que nous?” Institut C.D. Howe commentaire $N^{\circ} 529$.

January 2019 Mahboubi, Parisa. “Intergenerational Fairness: Will Our Kids Live Better than We Do?” C.D. Howe Institute Commentary 529.

January 2019 Goulding A.J., with research support from Jarome Leslie. "Dammed If You Do: How Sunk Costs Are Dragging Canadian Electricity Ratepayers Underwater” C.D. Howe Institute Commentary 528.

January 2019 Kim, Jacob, and Alexandre Laurin. "Mothers at Work: The Fiscal Implications of the Proposed Ontario Childcare Rebate.” C.D. Howe Institute E-Brief.

December 2018 Robson, William B.P., and Farah Omran. Wild Numbers: Getting Better Fiscal Accountability in Canada's Municipalities. C.D. Howe Institute Commentary 527.

\section{SUPPORT THE INSTITUTE}

For more information on supporting the C.D. Howe Institute's vital policy work, through charitable giving or membership, please go to www.cdhowe.org or call 416-865-1904. Learn more about the Institute's activities and how to make a donation at the same time. You will receive a tax receipt for your gift.

\section{A REPUTATION FOR INDEPENDENT, NONPARTISAN RESEARCH}

The C.D. Howe Institute's reputation for independent, reasoned and relevant public policy research of the highest quality is its chief asset, and underpins the credibility and effectiveness of its work. Independence and nonpartisanship are core Institute values that inform its approach to research, guide the actions of its professional staff and limit the types of financial contributions that the Institute will accept.

For our full Independence and Nonpartisanship Policy go to www.cdhowe.org. 

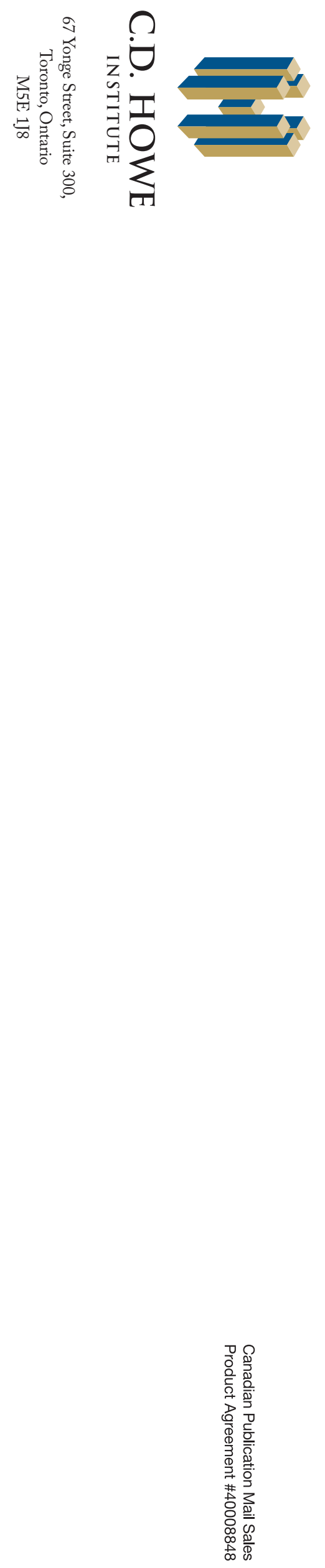